\title{
Life Cycle based Framework for Urban Solid Waste Management for Local Authorities
}

Mutu Tantrige Osada Vishvajith Peiris ( $\nabla$ vishvajithp@uom.lk)

University of Moratuwa https://orcid.org/0000-0001-5802-9517

Gileemalege Lalithri Navodya Dayarathne

University of Moratuwa

\section{Research Article}

Keywords: Solid Waste Management, Life Cycle Assessment (LCA), Environmental Impacts

Posted Date: May 7th, 2021

DOl: https://doi.org/10.21203/rs.3.rs-457184/v1

License: (9) This work is licensed under a Creative Commons Attribution 4.0 International License. Read Full License 


\title{
LIFE CYCLE BASED FRAMEWORK FOR URBAN SOLID WASTE MANAGEMENT FOR LOCAL AUTHORITIES
}

\author{
Mutu Tantrige Osada Vishvajith Peiris * and Gileemalege Lalithri Navodya Dayarathne \\ Department of Town \& Country Planning, Faculty of Architecture, University of \\ Moratuwa. \\ * Corresponding author \\ Email: vishvajithp@uom.lk
}

\section{Abstract}

This paper explores for an impact based framework in determining the sustainable waste management strategy for local authority level. Application of Life Cycle Assessment (LCA) based framework predicted the potential negative and positive impacts of each stage of waste management process and compared different future scenarios to identify the integrated SWM strategy. Low-cost and land availability-based waste management methods are known to be ineffective and impact-based sustainable solid waste management (SWM) strategies are limited in the local authorities of Sri Lanka. A frequent debate was seen between incineration and sanitary landfilling as the final disposal method as opinion surveys and cost based approaches have limited focus on scientific evaluation of impacts. This study used Emission Quantification Tool (EQT) to calculate the impacts of waste management process with five (05) future scenarios of waste integration including the Business-As-Usual scenario. Expert opinion survey was conducted in validation the outcomes and prioritization of scenarios. The selected local authority was Dehiwala-Mount Lavinia Municipal Council (DMMC) as the case study. The results were obtained by considering the $\mathrm{CO}_{2}$ emissions equivalent for one ton of solid waste where BAU scenario had the highest negative impacts with open dumping as the current practice of end disposal. Incineration method as the main disposal method had highest positive impacts while sanitary landfilling at Aruwakkalu (200km away from the source) had moderate positive impacts mainly due to the emissions caused by the transportation and processing. Recycling and Anaerobic Digestion (AD) was considered priority steps to improve the positive impacts of the waste management process. EQT model can be used to compare future scenarios to support decision makers on effective integration of waste management techniques. The study revealed that emissions during transportation and open burning are significant, yet considered less in selecting waste management process. This study can be further developed to compare scientific evaluation methods with financial and resource based criteria to make decisions on SWM.

Key Words: Solid Waste Management, Life Cycle Assessment (LCA), Environmental Impacts 


\section{Introduction}

Waste management is an issue for many developing countries in the world due to population increment, urbanization and the rapid economic activities (Rahman \& Al-Muyeed, 2010) Especially many local authorities (LA) in Sri Lanka, become urbanized and facing difficulties in Waste Management (Menikpura, Gheewala, \& Bonnet, 2012). Disaster caused by the collapse of Meethotamulla open dump was a result of poor planning and negligence of long term impacts (Daily News, 2017; RoarMedia, 2017). Open dumping was highly criticized as an unsafe disposal method in terms of impacts. Therefore, finding an effective solid waste management (SWM) strategy is a pre requisite for planning of urban areas. Sri Lanka generates approximately 7000 tonnes of waste per day in which 50\% is from Western Province (EFL, 2017) Waste management functions have been assigned to local authorities in Sri Lanka. There are various institutions working on waste management issues in Sri Lanka to manage the pollution and related negative impacts and short term biodegradable waste is about $60 \%$ of total composition in Sri Lanka (Premachandra, 2006) which have caused number of issues around dumping sites.

Waste management strategy of many developing countries is determined by cost, land requirements, availability of expertise, reliability and convenience of the facilities available in a specific local authority (Sharholy, Ahmad, Mahmood, \& Trivedi, 2008). This situation is no different in Sri Lanka where SWM decision of LAs constrained by lack of financial resources. The rising waste generation will be another challenge while weak management of transportation and disposal has been the bottleneck for local authorities to be progressive (Dharmasiri, 2020). Therefore, the understanding the impacts within life cycle of solid waste is compulsory for effective decision making at local authority level. SWM can be different from developing countries to developed countries as per economic, environmental and social impacts are different (Olawoyin, et al., 2015). Open dumping of waste is the common practice for many developing countries (Berkun \& Nemlioglu, 2015) where poor management and operation have created waste disposal a national level problem in Sri Lanka (Wijerathna \& Mangalika, 2012). Moreover, decision makers at LAs depend on cost minimization and other non-scientific methods in selecting the SWM mechanism where potential future impacts were hardly identified in the planning stage. Therefore, evaluation of long term impacts of SWM strategies before decisions are made is a timely need with the use of appropriate tools and techniques to assess life cycle of waste.

Life Cycle Assessment (LCA) used as a tool to assess the environmental impacts by considering the life cycle of waste streams from cradle to grave. A few research was conducted by previously in Sri Lanka to evaluate SWM strategies by using LCA approach. Therefore, the research question of this study has been formulated as:

72 How could an environmental impacts based assessment approach support the decision 73 makers at local authorities in deriving optimum waste management strategy? 
The study expected to develop an emission based impact framework to assess different SWM strategies in Sri Lankan context to determine the optimum management mix that maximize the environmental benefits.

The research objectives are as follows:

1 To identify the key emission based impact categories of solid waste management in Sri Lanka

2 To compare the significant anticipated impacts in different waste management scenarios

3 To derive conclusions to support decision makers a comprehensive SWM strategy based on environmental impacts

This research was conducted to test LCA based assessment framework for solid waste management and only considered the initial air emission categories during collection, transportation, processing and end disposal stages of solid waste. Dehiwala Mount-Lavinia Municipal Council (DMMC) was selected as the case study due to availability of various SWM strategies and reliable data. The study is unique to the selected LA, and results could be generalized with similar waste composition and management strategies. Also the direct and indirect socio-economic impacts were considered static during the study.

\section{Literature Review}

\subsection{Need of Impact based Assessment for Solid Waste Management}

Traditionally, SWM decisions were made on the basis of economic costs and returns while today, the knowledge and technology has provided pathways to identify and simulate vast direct and indirect impacts (McDougall, White, Franke, \& Hindle, 2001; Singh \& Sharma, 2016). Decision makers at developing countries focused on short term cost effective waste management methods and face the dilemma in comparing advanced waste management options at a lower cost while sustainability considerations and technological improvements have caused pressure for long term solutions (Wilson, Smith, Blakey, \& Shaxson, 2007; Zurbrugg, 2002). As a developing country, Sri Lanka also facing similar situation. Collapse of Meethotamulla garbage dump was an eye opening to assess the sustainability of existing SWM strategy in Sri Lanka. Sustainable SWM strategy must be environmentally effective, economically affordable and socially acceptable (Woolridge, Ward, Phillips, Collins, \& Gandy, 2006). Reduction of human health impacts and environmental pollution controls are key objectives in managing the solid waste (Allesch \& Brunner, 2014) due to various diseases and pollution in many urban areas.

Decisions made on SWM strategy in the past considering least cost option have brought many impacts for present and future. Ensure the conservation of available natural resources and minimum pollution in the selection of acceptable SWM method is challenging (Gehrmann, Hiebel, \& Simon, 2017). Model based framework is a supporting structure in decision making in SWM which could focus on comprehensive view of waste life cycle. Therefore, a systematic framework 
could assist a proper selection on SWM strategies with strong logical explanations and statistics (Morrissey \& Browne, 2004).

\subsection{Decision Making Tools for Sustainable Solid Waste Management}

Even though SWM plans must consider economic, technical, environmental, regulatory needs while balancing the sustainability and social considerations (Barton, Dalley, \& Patel, 1996), sometimes SWM decisions derived from various tools can be contradictory due to different criteria used (Allesch \& Brunner, 2014). Therefore, the type of tools used for the assessment will depend on the contextual needs and level of treatment required. The cheapest option would not be the best option in WM since the environmental damages caused by such operation could not be trade-off through monetary values. Environmental impacts include the impacts to air, water, soil and resource consumption ( $\mathrm{Su}$, Hung, Chao, \& Ma, 2010) which eventually can be related to economic and social impacts too. Also, the qualitative analysis through expert opinion on impact assessment cannot be used as a rationale method of decision making due to two reasons. First is that expert opinion can be limited to specific technology and there can be new technologies targeting unforeseeable impacts of waste management. Second is the qualitative assessment make it difficult to compare the impacts at different stages due to the vague interpretation of magnitude and significance of impacts at each stage. Generally quantifiable impact could prove the level of impact so planners can make decisions to minimize the impacts. Fundamental aims of a WM model are to minimize environmental impacts, maximize material and energy recovery and reduce the societal costs associated with all the steps of WM (Morrissey \& Browne, 2004).

\subsection{Life Cycle Assessment (LCA) for Decision Making of Solid Waste Management}

Life cycle assessment (LCA) evaluates the environmental impacts through multiple actions and processes of waste life cycle (Gehrmann, Hiebel, \& Simon, 2017). LCA deals with quantitative evaluation and always reveal the facts with quantified data. Also simplicity of LCA framework is another primary strength (Karmperis, Aravossis, Tatsiopoulos, \& Sotirchos, 2013). Karmperis (2013) mentioned that, key benefit of the application of LCA was assessment of long-term environmental benefits compared with other tool options. The key steps in LCA application include (1) define boundary, goals and scope, (2) inventory of life cycle activities, (3) assessment of impacts in each category and (4) interpretation of the results. LCA has been commonly used as an assessment method to support SWM decision making. Menikpura, et al., (2012) have conducted an assessment of SWM strategy by using indicators for environment, economic and social aspects in Thailand where ecosystem damage and resource depletion was considered to evaluate environmental impacts. Lutz et al. (2006) considered impacts on wellbeing of the community and health indicators to assess social sustainability and Sudhir, et al. (1997), addressed impacts on urban poor to evaluate the sustainability of SWM strategy. 
3. Research Methodology

\subsection{Assessment of Impact Categories}

147

148

149

150

151

152

153

154

155

156

157

158

159

160

161

162

163

164

165

166

167

168

169

170

171

172

173

174

175

176

177

The impacts of waste management strategies on land-use, socio-economic and environmental sectors were identified and the emissions in each step of life cycle of waste were considered. Life Cycle Inventory (LCI) listed out the indicators in each of the management steps of waste management process namely: Collection and Transportation, Processing and Final Disposal. The system boundary in LCA was the monthly collection quantity of domestic waste by the local authority and the functional unit (FU) was taken as "kg of emissions per ton of waste". Key steps followed in the model were illustrated in Annexure 03. Global climate change was considered the key indicator for the assessment considering key Green House Gas (GHG) emissions namely: $\mathrm{CO}_{2}$, $\mathrm{CH}_{4}$, and CFC (Refer to Table 01, Annexure 01).

Impacts in different waste cycle steps in composting, recycling, open dumping, sanitary landfill and waste to energy plants were conducted by using Emission Quantification Tool (EQT) developed by Institute for Global Environmental Strategies (IGES). EQT is an aid tool to quantify and assess the emissions in the form of GHGs, BC (Black Carbon) and SLCP (Short Lived Climate Pollutants). For impact assessment, primary data was collected from the operational steps of waste life cycle different actors of waste management process while standard data was collected from recent literature. The required types of data were classified as per Table 02, Annexure 02.

Key waste management techniques considered for the study were Composting, Anaerobic Digestion (AD), Recycling, Incineration and Sanitary Landfilling. Open dumping was considered to assess the BAU scenario and impacts of waste collection, transportation (as vehicular emissions) and transfer stations were also considered in the assessment. Series of semi structured interviews were conducted with professionals in both government and private sector institutes on scenario development, impact prioritization of SWM and for the validation of the results. The key steps followed in the research design process are as shown in the Figure 1. 
179

Source-: Prepared by Author

Data Collection under selected impact identification framework (LCI)

Impact assessment under identified impact categories by using Emission Quantification Tool (EQT)

Evaluation of impact based scenarios for DMMC

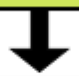

Development of impact based SWM framework \& validation
Case study site selection Dehiwala-Mount Lavinia Municipal Council

\subsection{Case Study}

DMMC is one of the highly urbanized local authorities in Sri Lanka with a population of 200,219 (2019). Existing waste generation amounts to approximately 186 tons per day while about $83 \%$ is collected on a daily basis (154 tonnes). Composting, AD and Recycling are managed within the local authority boundary which amounts to $16 \%, 7 \%$ and $21 \%$ of total collected waste respectively. Current final disposal site of DMMC is Karadiyana open dumping site (KDS) which is within $5 \mathrm{~km}$ of local authority boundary. For the future scenario development, proposed Incineration plant at KDS and Sanitary Landfill at Aruwakkalu (ASL) in Puttlam (200km away from DMMC) were considered. 


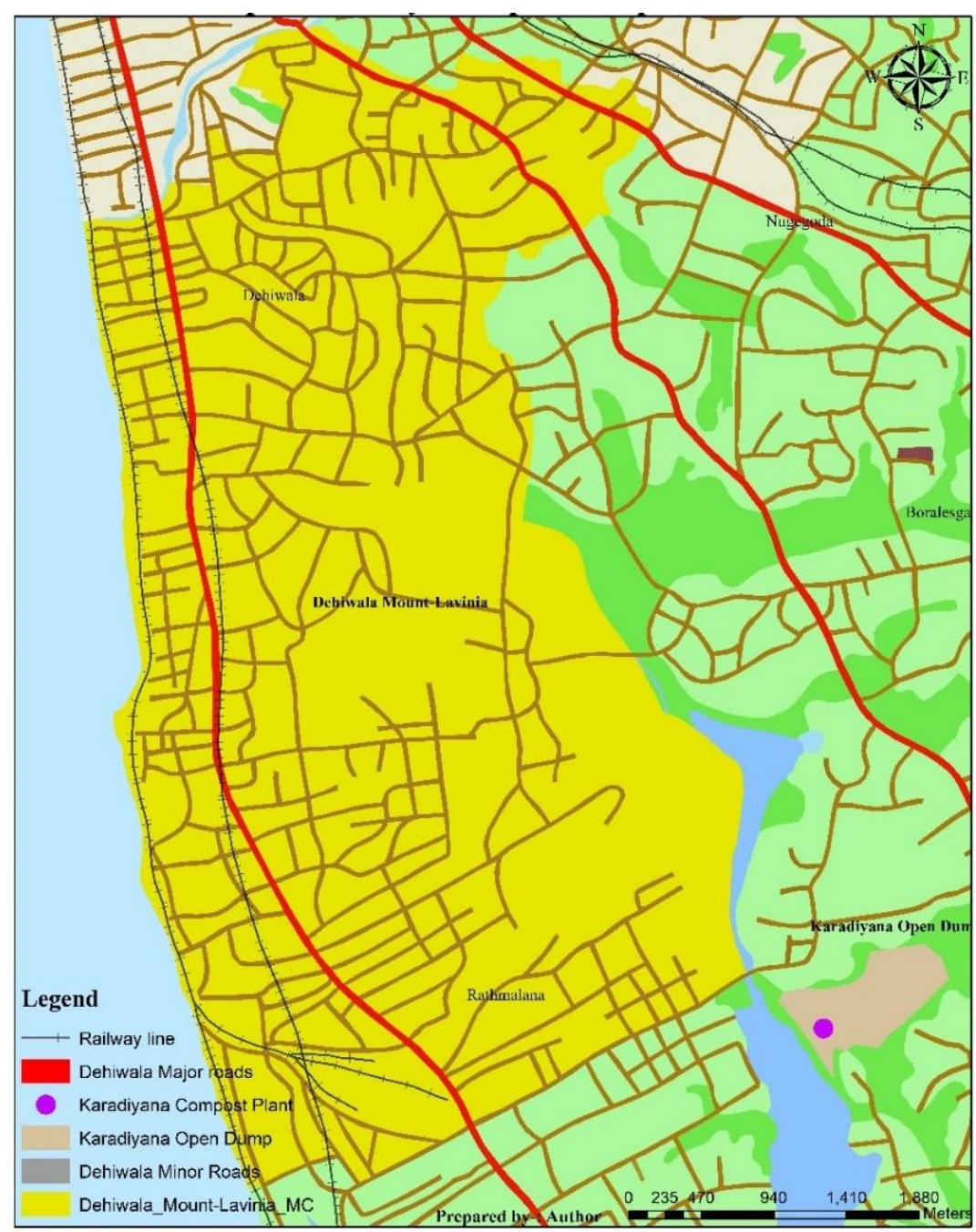

Source-: Prepared by Author

\subsection{Life Cycle of $M S W$ at DMMC}

The life cycle of MSW of DMMC was depicted in Figure 3 as DMMC collect the waste under two main streams namely: mixed waste and recyclable waste. Recycling is handled at Badowita recycling center where both formal and informal collection takes place. Mixed waste includes several waste types namely; MSW, bulky waste, industrial waste, slaughter house waste and sorted organic waste. According to the BAU scenario, 154 tonnes of waste was collected by the formal collectors on a daily basis. For one day 28 tonnes of waste were transferred to composting and 39 tonnes of recyclables were transferred to Badowita center to sell. The remaining 88 tonnes of mixed waste was transferred to Karadiyana for open dumping. 


\section{Life cycle of MSW of DMMC - BAU practice}

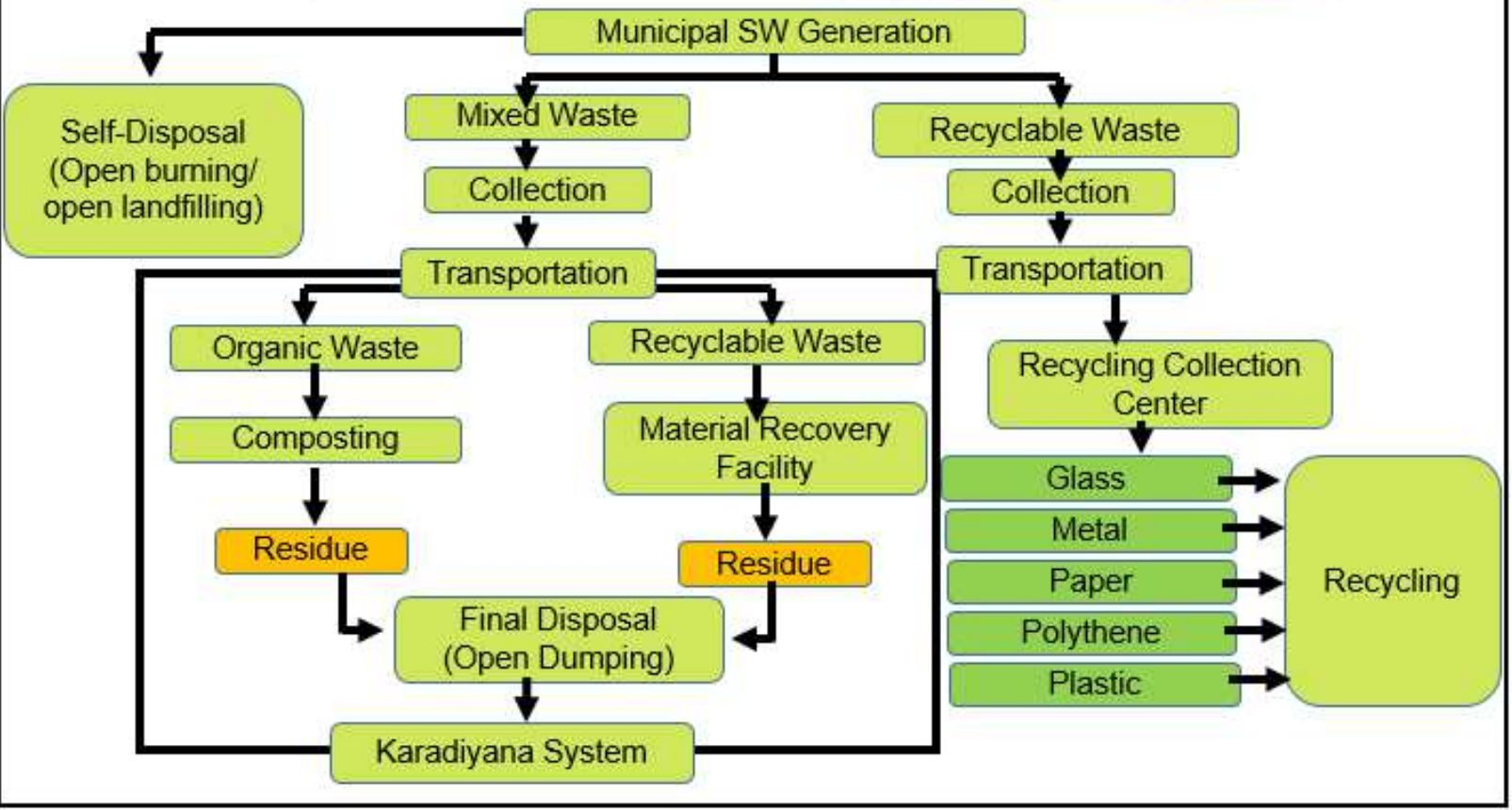

Source-: Discussions by Dehiwala-Mount Lavinia Municipal Council

\subsection{Development of Alternative Scenarios}

The gap between generated waste and collected waste was considered to be minimized in alternative scenarios. First scenario included composting, recycling and anaerobic digestion as key techniques and final disposal at Karadiyana (KDS). Waste mix in each scenario was based on the composition of waste for the past 20 years, expert opinion and recommendations of waste management agencies.

Scenario One (01) was developed based on DMMC capacity to manage waste with existing resources similar to BAU scenario. Scenario 01 considered no incineration of waste while about $50 \%$ of collected waste received by KDS. Scenario Two (02) considered approximately $30 \%$ of the waste for incineration at Karadiyana and about $20 \%$ of the waste for sanitary landfill at Aruwakkalu (ASL). ASL operation considered 20km distance from DMMC to transfer station at Kelaniya and $180 \mathrm{~km}$ distance from Kelaniya to ASL at Puttlam by train. Scenario Three (03) considered complete incineration of biological waste at Karadiyana and disposal of ash as semi aerobic landfill at KDS premises. About $70 \%$ of the total waste was delivered to ASL in the Scenario Four (04).

Recycling of waste was about $25 \%$ of total collected waste in each scenario and the impacts from recycling considered static throughout. AD was considered in scenarios 01 and 02 which was about 6-8\% of total collected waste. Composting was considered equally in BAU and scenarios 01 and 
$24702(18 \%)$ while scenario 04 had $5 \%$ of waste composted. Further details on scenario formulation 248 is as per the Table $1 \&$ Annexure 05.

249 Table 1: Composition of waste in each Scenario

\begin{tabular}{|l|l|l|l|l|l|l|}
\hline Utilization of MSW & Units & BAU & $\begin{array}{l}\text { Scenario } \\
01\end{array}$ & $\begin{array}{l}\text { Scenario } \\
02\end{array}$ & $\begin{array}{l}\text { Scenario } \\
03\end{array}$ & $\begin{array}{l}\text { Scenario } \\
04\end{array}$ \\
\hline $\begin{array}{l}\text { Collected waste by } \\
\text { formal collectors }\end{array}$ & Tonnes/day & 154 & 166 & 175 & 185 & 182 \\
\hline Composting & $"$ & 28 & 30 & 30 & 0 & 10 \\
\hline Anaerobic Digestion & $"$ & 0 & 14 & 11 & 0 & 0 \\
\hline Recycling & & 39 & 42 & 44 & 45 & 45 \\
\hline MBT & $"$ & 0 & 0 & 0 & 0 & 0 \\
\hline Incineration & $"$ & 0 & 0 & 50 & 125 & 0 \\
\hline $\begin{array}{l}\text { Landfilling/Open } \\
\text { dumping }\end{array}$ & $"$ & 87 & 80 & 40 & 15 & 127 \\
\hline
\end{tabular}

Source-: Prepared by Author as a result of expert opinion survey

251 Collection of waste in each scenario was increased from 154 tonnes/day (BAU collection) to 185 252 tonnes/day (Total generation). Collected waste by informal sector in DMMC was reported as 2 253 tonnes/day. It was assumed that waste collection in the informal sector as static except for the 254 scenario 04, in which assumed as 5 tonnes/day. In BAU practice, there were 31 tonnes of 255 uncollected waste per day and it was assumed that collection reached $100 \%$ and there was no 256 uncollected waste in $3^{\text {rd }}$ and $4^{\text {th }}$ scenarios. (Figure 4)

257 Figure 4: Summary of waste generation, collection and utilization

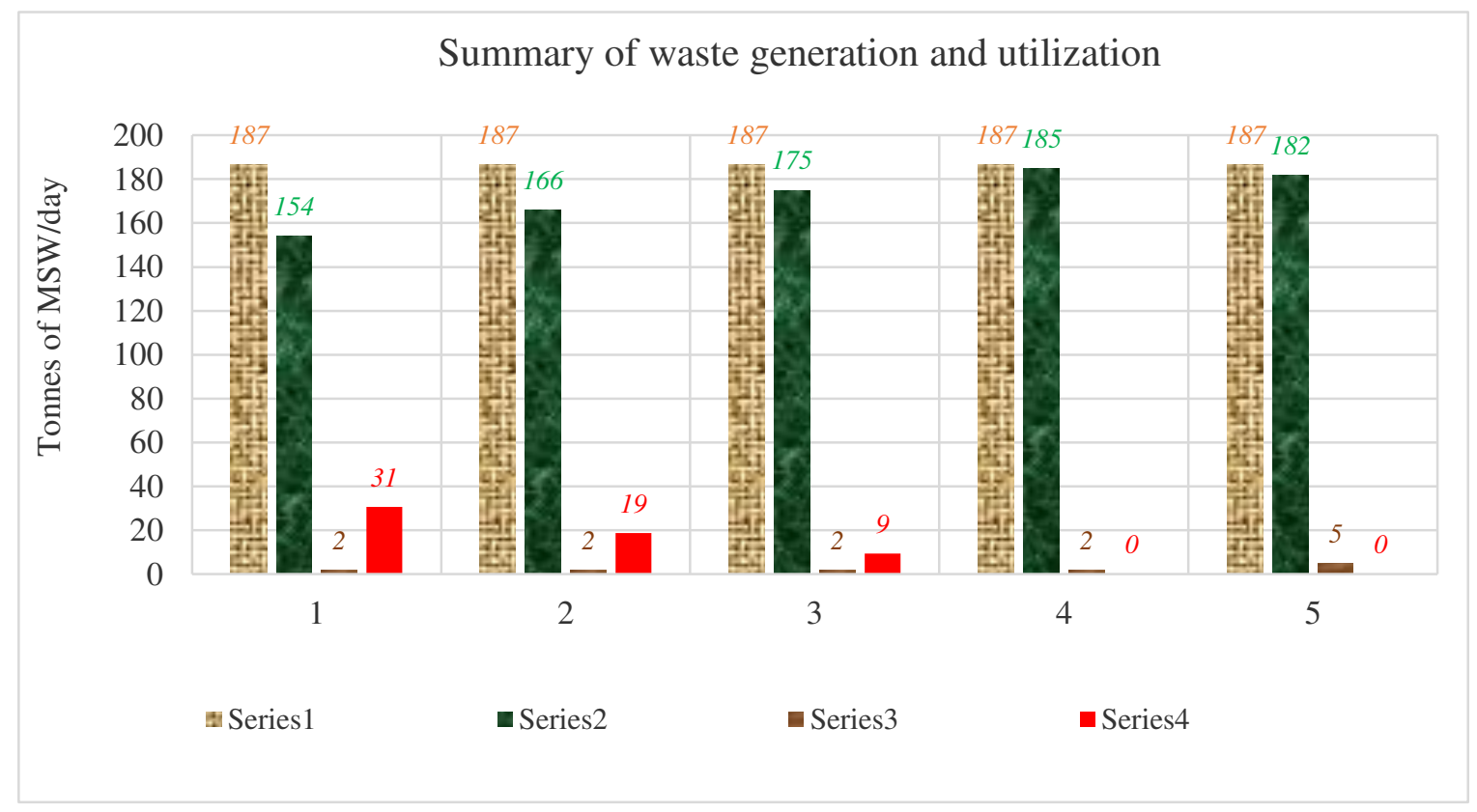


259 Scenarios BAU and 01 were operated by the both modern and older trucks while scenarios 02,03 and 04 used modern carrier trucks. Diesel was the fuel type for all modes and average fuel consumption for compactor $\left(8 \mathrm{~m}^{3}\right.$ capacity) was $23.71 \mathrm{l} /$ day and for dump truck/ tractor $\left(2 \mathrm{~m}^{3}\right.$ capacity) it was recorded as $6.58 \mathrm{1} /$ day. Modern carrier trucks $\left(12 \mathrm{~m}^{3}\right.$ capacity) had fuel consumption as 251/day in its operation. In the BAU scenario, 10 compactors and 37 dump trucks were used while in the scenario 01, 12 compactors and 35 dump trucks were used. Also 15 carriers were used for waste transport in scenarios 2 and 4 while 16 trucks required for scenario 3 . Refer Annexure 06 \& 07.

\section{Analysis}

The analysis was conducted to assess the impacts of 05 alternative scenarios (including BAU) of waste management at DMMC. The calculations were completed by the application of EQT tool and results were validated by experts. As per the experts and DMMC officials, LCA based model was applied for the DMMC to advise on the decision making of SWM.

\subsection{Scenario Analysis}

Considering the transportation stage, scenario 02 showed the highest climate impact of GHG significant emissions as climate impact was about 3 times higher than managing at KDS.

Figure 5: Net climate impact from transportation

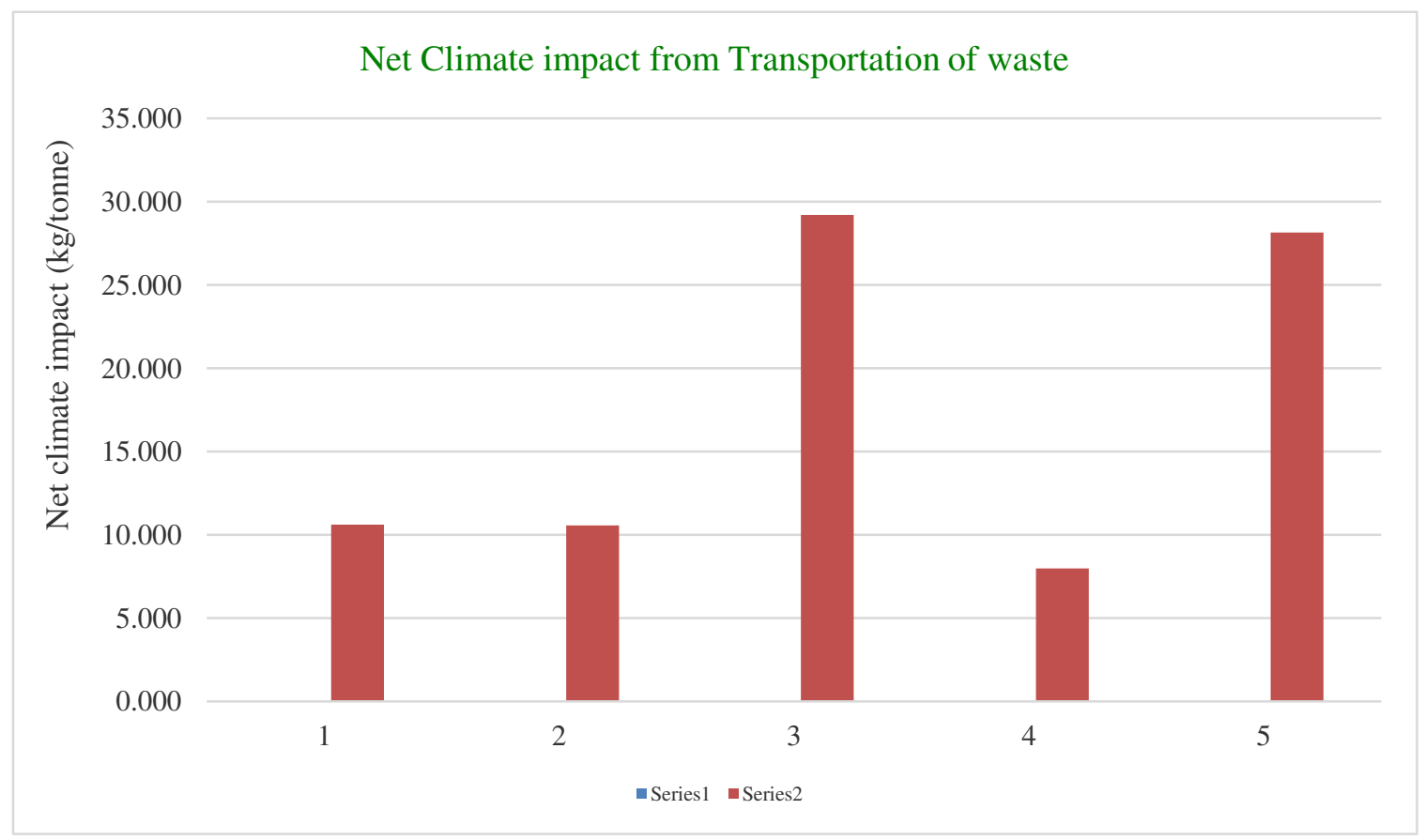


279 The net climate impact from composting in scenario 01,02 and 04 was recorded as $197.88 \mathrm{~kg}$ of $280 \mathrm{CO}_{2}$-eq/tonne which had equal amount of emissions. Figure 6 shows the net climate impact from 281 composting. All the scenarios had similar negative impact on environment. Compostable waste 282 content was considered stable (approximately 30 tonnes per day) asper the existing capacity of 283 composting plants at DMMC boundary.

Figure 6: Net climate impact from composting

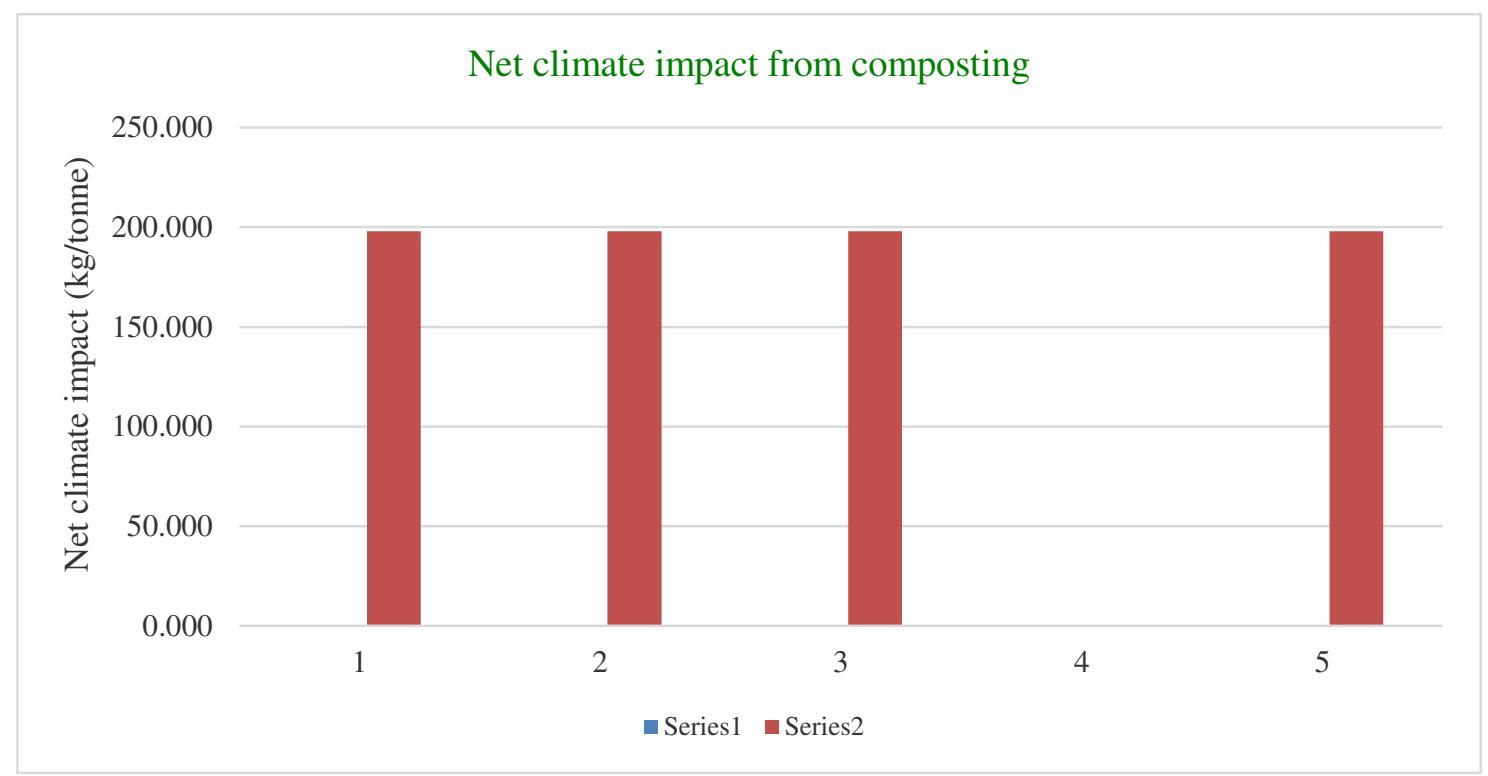

Source-: Prepared by Author

$\mathrm{AD}$ was only used in scenarios 01 and 02 which shows negative outcomes. Emission savings were higher than emission loss in AD. The net climate impact of GHGs in scenario 1 and 2 is recorded as $-178.02 \mathrm{~kg}$ of $\mathrm{CO}_{2}$-eq/tonne (Figure 7). The capacity of existing AD facilities was considered as 12-14 tonnes per day for calculations. 
Net climate impact from Anaerobic Digestion

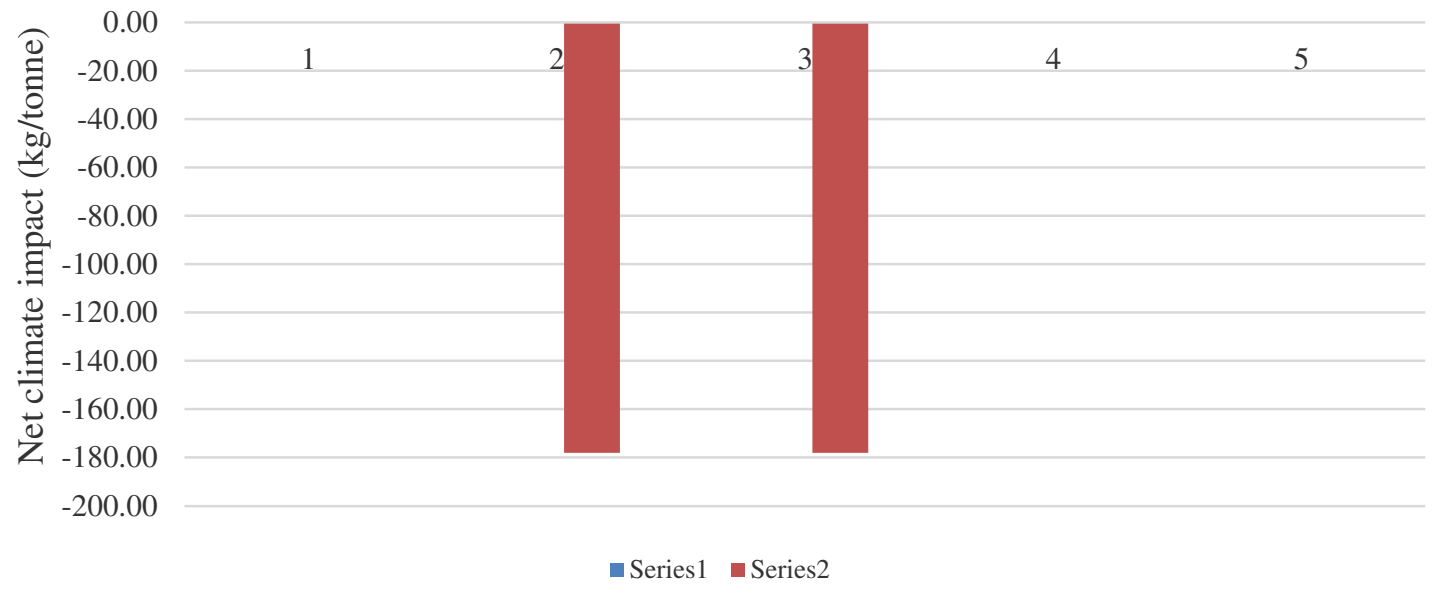

Source-: Prepared by Author

295
Net climate impact from recycling

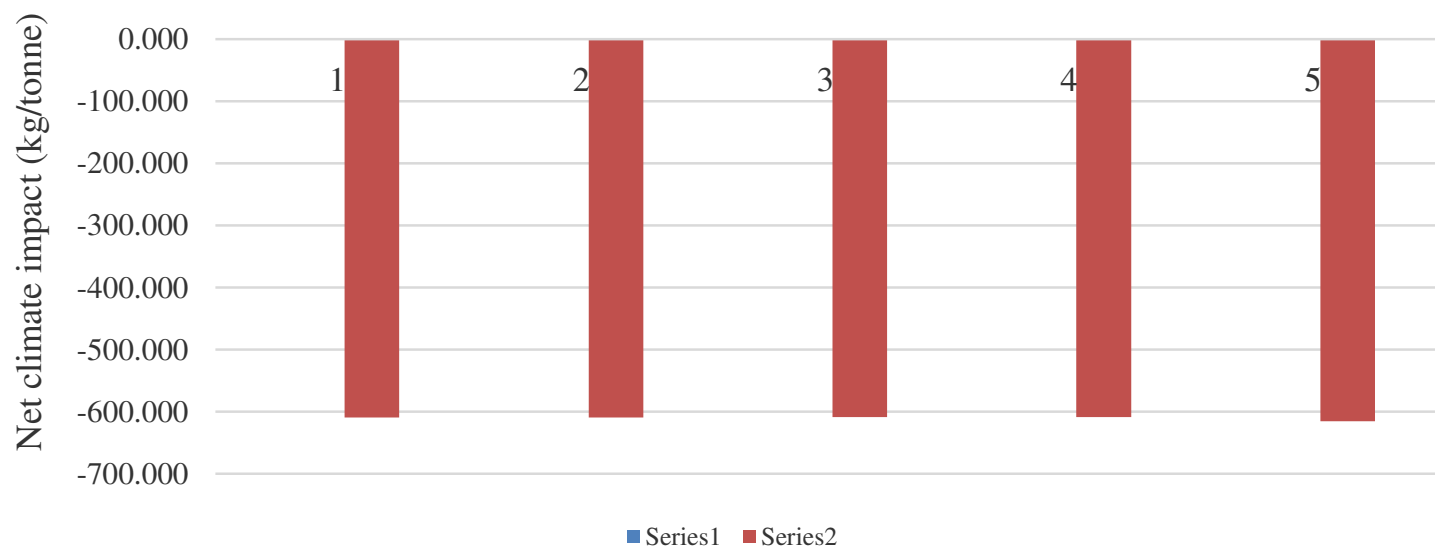

Source-: Prepared by Author

Incineration was used by scenarios 02 and 03 where both scenarios show negative outcomes. Among these, scenario 02 had the lowest negative value (highest gain value) and it was recorded as $-50.67 \mathrm{~kg}$ of $\mathrm{CO}_{2}$-eq/tonne. Figure 9 shows the net climate impact from incineration. 
Source-: Prepared by Author

310 Landfill and open dumping were considered as final disposal methods with technological differences in each scenario. Out of all, scenario 02 (40 tonnes at ASL) had the highest net climate impact and it is $1331.593 \mathrm{~kg}$ of $\mathrm{CO}_{2}$-eq/tonne. Scenario 04 (127 tonnes at ASL) had the least climate impact and it is $112.751 \mathrm{~kg}$ of $\mathrm{CO}_{2}$-eq/tonne. BAU and scenario 01 emit equal amount of emissions ( $530 \mathrm{~kg}$ of $\mathrm{CO}_{2}$-eq/tonne) where the both scenarios use $\mathrm{KDS}$ as open dump. Figure 10 shows the net climate impact from open dumping and sanitary landfills.

Figure 10: Net climate impact from landfill/open dumping

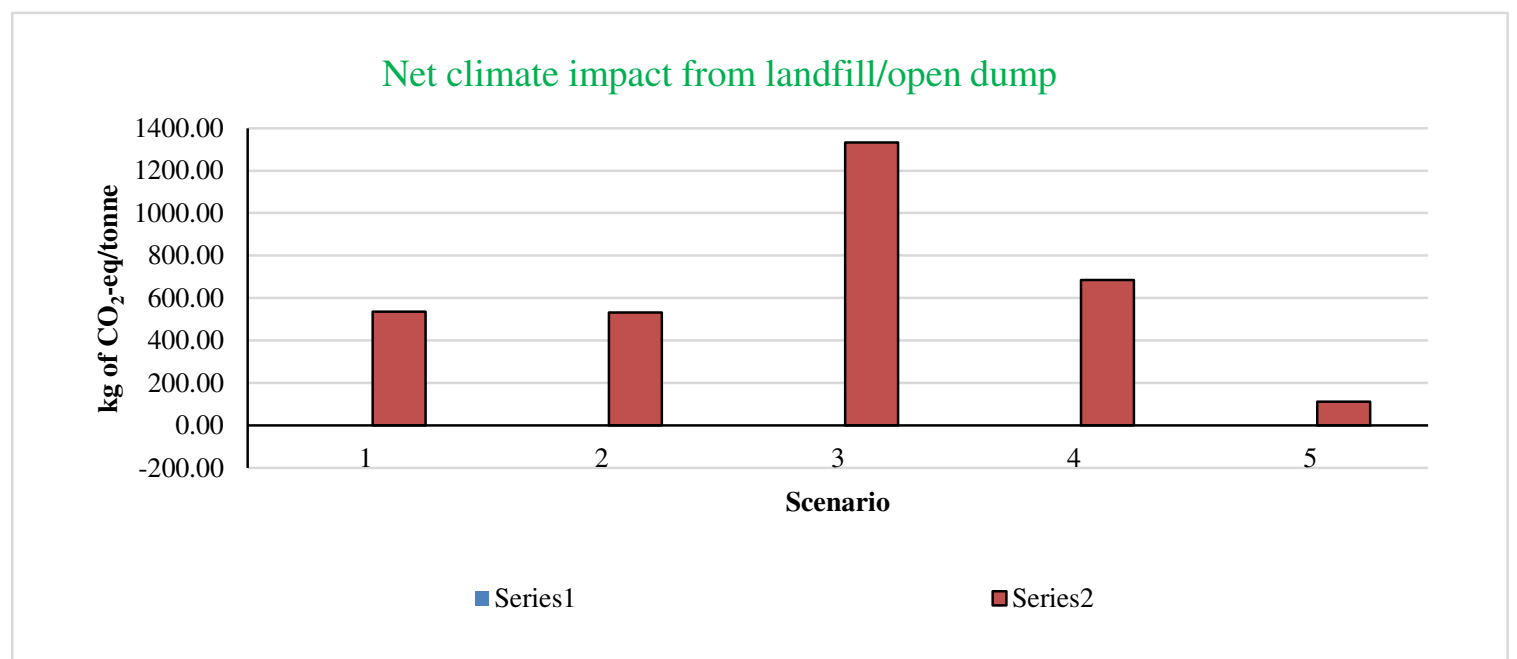

Source-: Prepared by Author

Scenario 03 and 04 were assumed as 0 uncollected waste. Scenarios 01 and 02 showed the highest climate impact from uncollected waste and it is recorded as $708.48 \mathrm{~kg}$ of $\mathrm{CO}_{2}$-eq/tonne of uncollected waste. Comparatively BAU scenario had lower emissions and it is shown in 321 Figure 11. 


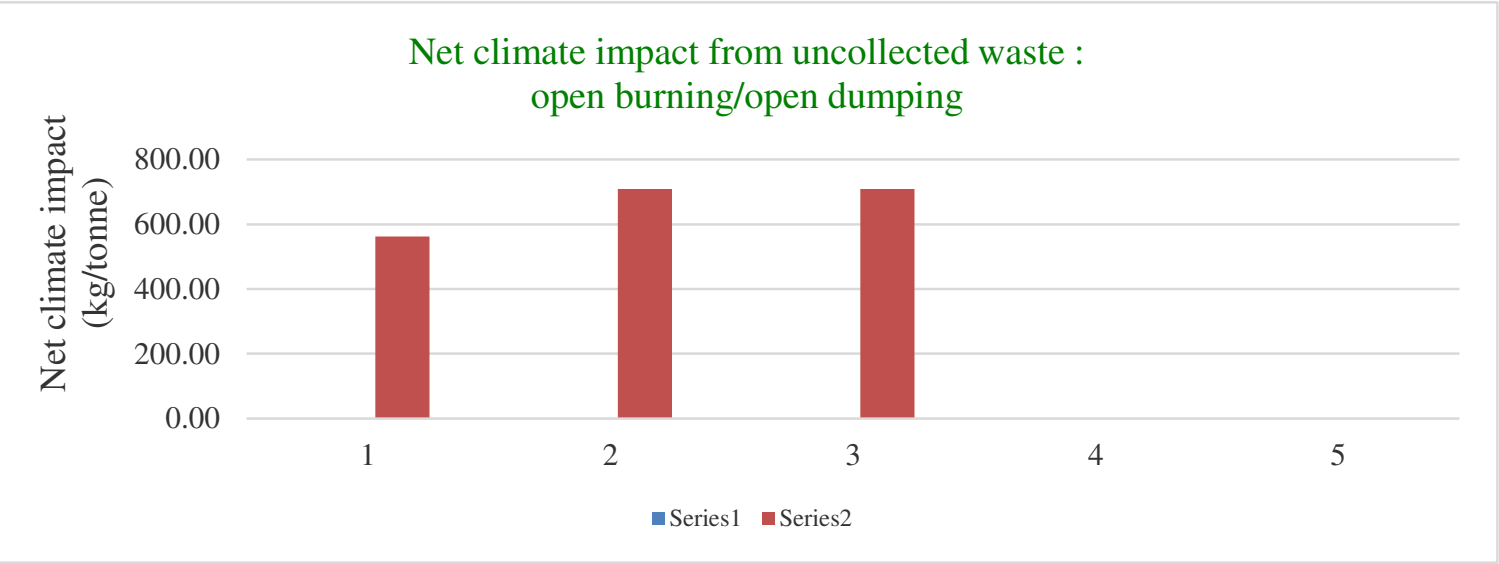

324 The assessment of the overall emissions during each scenario was considered to evaluate the impact 325 of each strategy. According to Figure 12, GHGs/SLPCs emissions show that each scenario had 326 negative values for $\mathrm{CO}_{2}$ emissions and scenario 04 showed the highest savings of $\mathrm{CO}_{2}$. Also the $\mathrm{CH}_{4}$ 327 emissions were highest in BAU and scenario 01 while lowest $\mathrm{CH}_{4}$ emissions were visible in scenario $32803 . \mathrm{N}_{2} \mathrm{O}$ emissions were equally low amounts in each scenario.

Figure 12: GHGs/ SLCPs emissions by Scenario

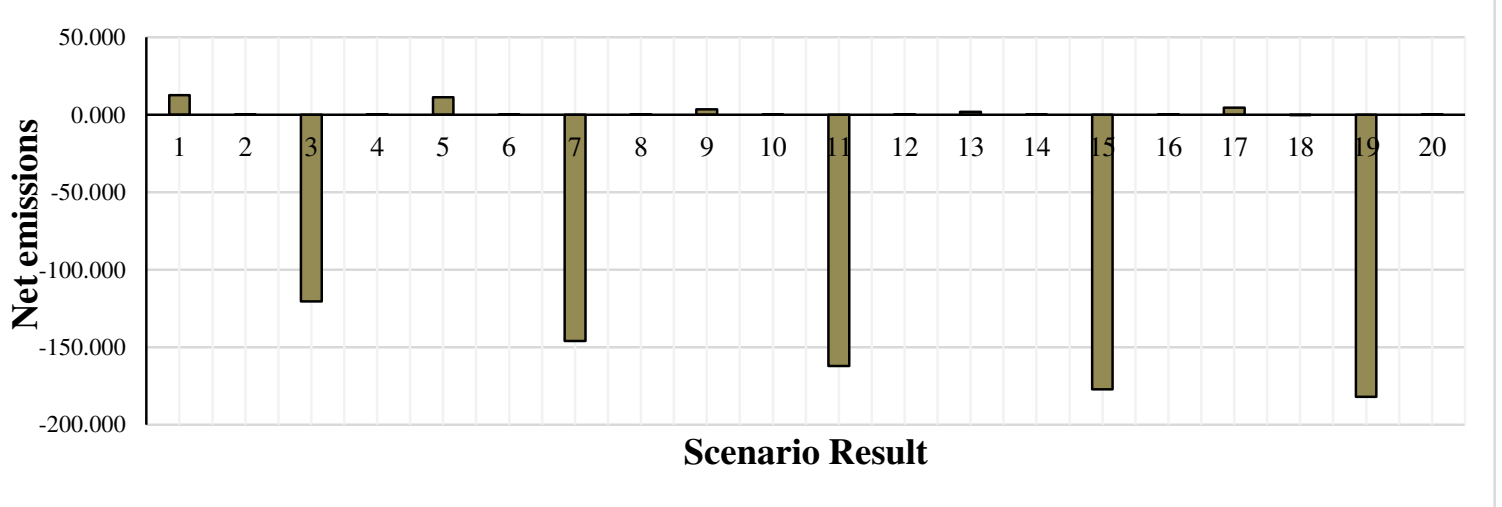

Source-: Prepared by Author based on EQT Framework

The impact on climate based on GHG emissions was shown in Figure 13. BAU and Scenario 01 333 show positive impact while other scenarios show negative emissions which means positive for the 334 environment. Scenario 03 had the least impacts on the environment while BAU scenario had the 335 highest negative impacts from GHG perspective. 
口Climate impact from GHGs emissions per tonne of generated waste: $\mathrm{kg}$ of CO2-eq/tonne

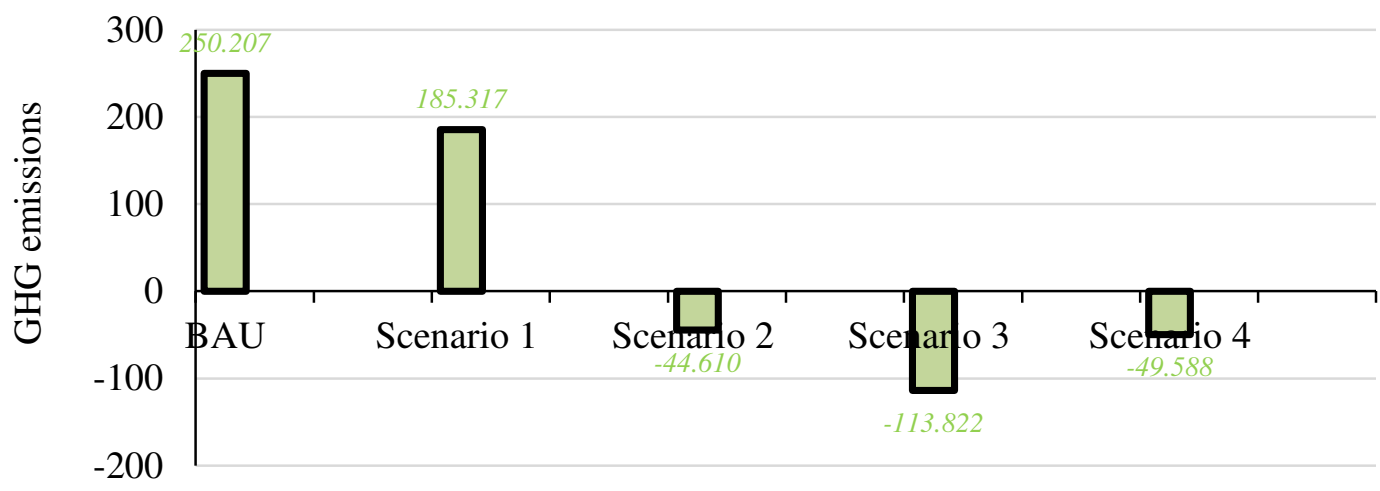

Source-: Prepared by Author based on EQT Framework

\section{Conclusion and Recommendations}

This study investigated on the application of life cycle based SWM assessment framework to support the decision makers in local authorities. From the collection of the waste from households, up to the final disposal at a landfill, the impacts can take various forms. So end disposal technique would not stand alone solve the negative impacts of SWM process. Distance of final disposal site from the waste generation point is an essential factor as DMMC must reassess the waste transportation to ASL which is over $200 \mathrm{~km}$ away from source. Anaerobic digestion could be a potential positive impact source for biodegradable waste as generation of energy would provide additional benefits. But the careful selection of waste streams for AD is a challenge for DMMC to expand the process. Recycling has been a potential positive impact for environment as recyclable waste comprised of $25 \%$ of total waste. Based on waste composition data, recycling rate has been stable for the past 10 years at DMMC. High quantities of organic waste were the key problem at DMMC where final disposal method was fluctuated in between sanitary landfill and incineration as the end disposal options available for DMMC to decide. Expert opinion survey results verified that sanitary landfilling could be an effective environmental friendly method for Sri Lanka, compared with open dumping and incineration. But due to the distance factor of ASL and other related negative impacts, incineration at KDS followed by sanitary landfill at the same location was the viable option for end disposal.

This research was conducted to identify an alternative framework to make decisions on integrated solid waste management strategy for local authorities. Accordingly, focus on recycling, incineration and sanitary landfill of the waste within manageable distance of local authority where it is approximately $10 \mathrm{~km}$ for DMMC. Elimination of uncollected waste and use of modern compactors with improved technology can be recommended for effective waste management. Expert opinion survey results verified that sanitary landfilling could be an effective environmental friendly method for Sri Lanka, compared with open dumping and incineration (Refer Annexure 08 \& 09). Since Sri Lanka is a developing country, budgetary allocation for SWM is comparatively 
low. Also many collection vehicles and equipment in local authorities were too old and broken causing various emissions. But experts did not reach consensus about the statement about GHG emissions and most impactful category of MSWM systems. The lack of understanding of future impacts by LAs could lead in to inaccurate decision making in strategy selection that could cause irreversible impacts.

The results proved that application of LCA based framework can identify the key impact categories during the life cycle of solid waste, and a valuable tool in SWM decision making. Impact prediction tools are essential before implementation of SWM strategies where many cities struggle with unsafe waste disposal sites in Sri Lanka. This research could be expanded to link the financial criteria for each waste management scenario to evaluate the economic impacts along with environmental impacts. Also, the tool can be used to determine the optimum location for waste disposal for a city along with the required capacity of each waste management scenario. Prediction of impact categories could be an important step, so the local authorities would not have to spend financial and human resources with trial and error of SWM strategies. Also the life cycle of solid waste supports the decision makers and managers to identify and manage solid waste management process with efficiency improvements.

\section{Acknowledgements}

Authors would like to sincerely thank the commissioner of Dehiwala Mount Lavinia Municipal Council for allowing the case study selection, Dr. Nirmala Menikpura who assisted with EQT tool to calculate the impacts and those who offered their support and freedom on completion of this research in various capacities

\section{About the authors}

Plnr. Mutu Tantrige Osada Vishvajith Peiris (OVP) is a researcher and lecturer at Department of Town \& Country Planning, University of Moratuwa. He holds BSc. Honors degree in Town \& Country Planning at University of Moratuwa, Sri Lanka and MSc. In Environmental Management at National University of Singapore, Singapore. Mr. Peiris has worked in both private sector and public sector agencies in the fields of urban and regional planning, waste water treatment, water management and infrastructure planning. Mr. Peiris is the corresponding author and can be contacted at vishvajithp@uom.lk.

Ms. Gileemalege Lalithri Navodya Dayarathne (LND) is a researcher and undergraduate at Department of Town \& Country Planning, University of Moratuwa. Ms. Dayarathne is the coauthor and can be contacted at lalithridayarathne@gmail.com.

\section{Authors' contributions}

OVP conceptualized the study and developed the methodology to validate the conceptualized model. LND collected the data, conducted the analysis, and documented the results. OVP assisted 
400 in writing the results and validation of the results with data. LND finalized the analysis section.

401 All authors, read, edited and approved the final manuscript.

$402 \quad$ Funding

403 Not applicable.

404 Availability of data and materials

405 Yes, authors can provide the supporting data if required.

406 Competing interests

407 The authors declare that they have no competing interests.

408 Author details

409 Department of Town \& Country Planning, University of Moratuwa, Katubedda, Sri Lanka.

6. References

412 Abeliotis, K. (2011). Life cycle assessment in municipal solid waste management.

413

414

415

416

417

418

419

420

421

422

423

425

426

427

428

429

430

Allesch, A., \& Brunner, P. H. (2014). Assessment methods for solid waste management: A literature review. Waste Management \& Research, 32(6), 461-473.

Allesch, A., \& Brunner, P. H. (2014). Assessment methods for solid waste management: A literature review. Waste Management \& Research, 32(6), 461-473.

Authority, C. E. (2006). Environmental Impact Assessment. Cleantech (Pvt.) Limited.

Authority, C. E. (n.d.). TECHNICAL GUIDELINES ON SOLID WASTE MANAGEMENT IN SRI LANKA.

Berkun, M. A., \& Nemlioglu, S. (2015). Disposal of solid waste in Istanbul and along the Black Sea coast of Turkey. Waste Management, 25(8), 847-855.

Boardman, A. E., Greenberg, D. H., Vining, A. R., \& Weimer, D. L. (2017). Cost-benefit analysis: concepts and practice. Cambridge University Press.

Braida, H. (2015). Sustainable municipal solid waste management decision making. Management of Environmental Quality: An International Journal., 26(6), 1-26.

Butu, A. W., Ageda, B. R., \& Bichi, A. A. (2013). Environmental impacts of roadside disposal of municipal solid wastes in Karu, Nasarawa State, Nigeria. International Journal of Environment and Pollution Research, 1(1), 1-19.

CEA. (2004). Technical Guideline on Solid Waste Management in Sri Lanka. Retrieved from Central Environmental Authority: http://www.cea.lk/web/images/pdf/Guidlines-on-solid-wastemanagement.pdf 
Chai, D. C. (2014, May 05). Life Cycle Assessment: an Introduction to Concepts and Applications. Retrieved from AZO CLEANTECH: https://www.azocleantech.com/article.aspx?ArticleID=516

Daily News. (2017, April 17). Meethotamulla tragedy: Consequences of negligence and lethargy? Retrieved from Daily News E Paper: https://www.dailynews.lk/2017/04/17/features/113310/meethotamulla-tragedy-consequencesnegligence-and-lethargy

Department of Census and Statistics. (2012). Census of Population and Housing .

Dharmasiri, L. M. (2020). Waste Management in Sri Lanka: Challenges and Opportunities. Sri Lanka journal of social sciences.

Dharmasiri, L. M. (2020). Waste Management in Sri Lanka: Challenges and Opportunities. Sri Lanka journal of social sciences.

EFL. (2017, June 14). Status of Waste Management in Sri Lanka. Retrieved from Environmental Foundation Limited Web site: https://efl.lk/status-waste-management-srilanka/\#: :text=Waste\%20collection\%20and\%20disposal\%20responsibilities,Pradeshiya\%20Sabh a\%20Act\%20\%E2\%80\%93\%201987).

Gehrmann, H. J., Hiebel, M., \& Simon, F. G. (2017). Methods for the evaluation of waste treatment processes. Journal of Engineering, 2017.

Gehrmann, H. J., Hiebel, M., \& Simon, F. G. (2017). Methods for the evaluation of waste treatment processes. Journal of Engineering.

IGES. (2018, June). Emission Quantification Tool for Estimation of GHGs/ SLCPs from Solid Waste Sector. Hayama, Kanagawa, Japan.

J.R., B., Dalley, D., \& Patel, V. (1996). Life cycle assessment for waste management. Waste Management, 16, 35-50.

Japan International Cooperation Agency. (2016). Data Collection Survey on Solid Waste.

Kadafa, A. A., Manaf, L. A., Azmin Sulaiman, W. N., \& Abdullah, S. H. (2014). Applications of System Analysis Techniques in Solid Waste Management Assessment. Polish Journal of Environmental Studies, 23(4).

Kaluli, W., Mwangi, H. M., \& Sira, F. N. (2017). SUSTAINABLE SOLID WASTE MANAGEMENT STRATEGIES IN JUJA, KENYA.

Karmperis, A. C., Aravossis, K., Tatsiopoulos, I. P., \& Sotirchos, A. (2013). Decision support models for solid waste management: Review and game-theoretic approaches. Waste management, 33(5), 1290-1301.

Lutz, J., Lekov, A., Chan, P., Whitehead, C. D., Meyers, S., \& McMahon, J. (2006). Life-cycle cost analysis of energy efficiency design options for residential furnaces and boilers. Energy, 31(2-3), 311-329.

Mahmood, K., Batool, S. A., Chaudhary, M. N., \& Ul-Haq, Z. (2017). Ranking criteria for assessment of municipal solid waste dumping sites. Archives of Environmental Protection, 43(1), 95-105. 
McDougall, F., White, P., Franke, M., \& Hindle, P. (2001). Integrated solid waste management: a life cycle inventory, 2nd edition. Oxford: Blackwell Publishing Company.

Menikpura, S. N., Gheewala, S. H., \& Bonnet, S. (2012). Framework for life cycle sustainability assessment of municipal solid waste management systems with an application to a case study in Thailand. Waste Management \& Research, 30(7), 708-719.

Menikpura, S. N., Gheewala, S. H., \& Bonnet, S. (2012). Sustainability assessment of municipal solid waste management in Sri Lanka: problems and prospects. ournal of Material Cycles and Waste Management, 14(3), 181-192.

Morrissey, A. J., \& Browne, J. (2004). Waste management models and their application to sustainable waste management. Waste management, 24(3), 297-308.

Mwanza, B., \& Phiri, A. (2013). Design of a waste management model using integrated solid waste management: A case of Bulawayo City Council. International Journal of Water Resources and Environmental Engineering , 5(2), 110-118.

Olawoyin, M. A., Nwaogu, C., Nakashole, P., Ahado, S., Toseafa, H. K., \& Gardiner, R. (2015). ENVIRONMENTAL AND SOCIO-ECONOMIC IMPACTS OF SOLID WASTE DUMPING AND BURNING ON THE MAJOR MOTORWAYS IN DEVELOPING COUNTRIES. International Journal of Recent Advances in Multidisciplinary Research, 2(12).

Peralta, P. (2011). Fuel Efficiency in Transportation. Delhi: The English Press .

Premachandra, H. S. (2006). Household Waste Composting \& MSW Recycling in Sri Lanka. In Asia 3R conference, Tokyo(available from: www. env. go. jp/recycle/3r/en/asia/02_03-3/08. pdf [Accessed 3 January 2011].

Rahman, M. H., \& Al-Muyeed, A. (2010). EVALUATION OF SOLID WASTE COMPOSTING IN BANGLADESH. Journal of Solid Waste Technology \& Management, 36(3).

Ramanathan, R. (2001). A note on the use of the analytic hierarchy process for environmental impact assessment. Journal of environmental management, 63(1), 27-35.

Rand, T. H. (2000). Municipal solid waste incineration: requirements for a successful project. World Bank Publications, 462.

RoarMedia. (2017, April 23). A Brief History Of The Meethotamulla Garbage Dump. Retrieved from Roar Media Web site: https://roar.media/english/life/reports/a-brief-history-of-themeethotamulla-garbage-dump

Saaty, T. L. (1990). Multicriteria decision making: the analytic hierarchy process: planning, priority setting resource allocation.

Şener, Ş., Sener, E., \& Karagüzel, R. (2011). Solid waste disposal site selection with GIS and AHP methodology: a case study in Senirkent-Uluborlu (Isparta) Basin, Turkey. Environmental monitoring and assessment, 173(1-4), 533-554.

Sharholy, M., Ahmad, K., Mahmood, G., \& Trivedi, R. C. (2008). Municipal solid waste management in Indian cities-A review. Waste management, 28(2), 459-467. 
Shekdar, A. V. (2009). Sustainable solid waste management: an integrated approach for Asian countries. Waste management, 29(4), 1438-1448.

Singh, P., \& Sharma, V. P. (2016). Integrated plastic waste management: environmental and improved health approaches. Procedia Environmental Sciences, 35, 692-700.

Site, C. N. (2013). Environmental Impact Assessment.

Su, J., Hung, M., Chao, C., \& Ma, H. (2010). Applying multi-criteria decision-making to improve the waste reduction policy in Taiwan. Waste Management \& Research, 28, 20-28.

Sudhir, V., Srinivasan, G., \& Muraleedharan, V. R. (1997). Planning for sustainable solid waste management in urban India. System Dynamics Review: The Journal of the System Dynamics Society, 13(3), 223-246.

Sudhir, V., Srinivasan, G., \& Muraleedharan, V. R. (1997). Planning for sustainable solid waste management in urban India. System Dynamics Review: The Journal of the System Dynamics Society, 13(3), 223-246.

Talaiekhozani, A. G. (2017). Evaluation of emission inventory of air pollutants from railroad and air transportation in Isfahan metropolitan in 2016. Journal of Air Pollution and Health, 2(1).

The World Bank. (2013). Solid Waste Management. Urban Development.

Tukker, A. (2000). Life cycle assessment as a tool in environmental impact assessment. Environmental impact assessment review, 20(4), 435-456.

Wijerathna, D. M., \& Mangalika, L. (2012). Solid waste generation, characteristics and management within the households in Sri Lankan urban areas.

Zurbrugg, C. (2002). Urban solid waste management in low-income countries of Asia how to cope with the garbage crisis. Presented for: Scientific Committee on Problems of the Environment (SCOPE) Urban Solid Waste Management Review Session, Durban, South Africa, 1-13. 
Figures

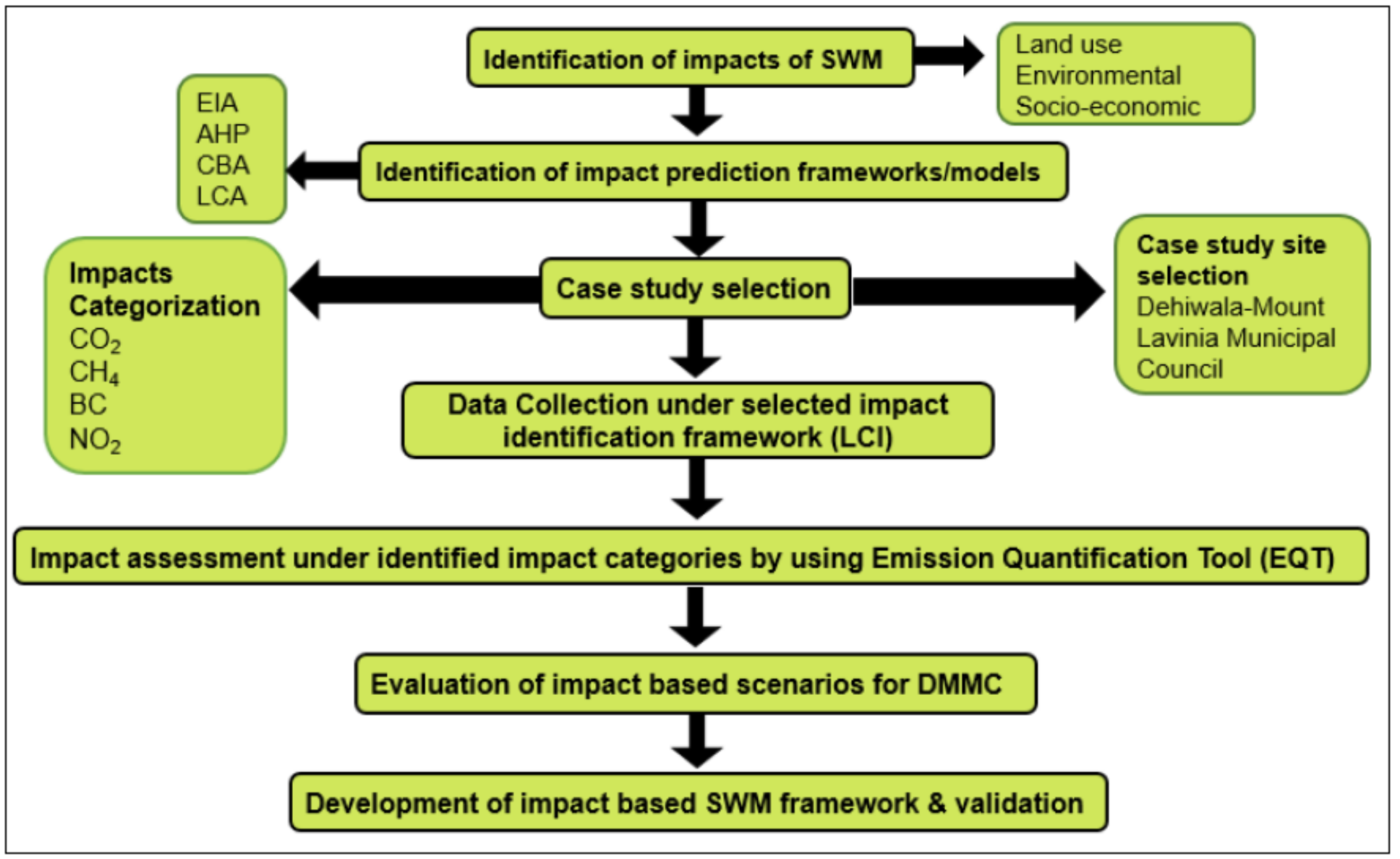

Figure 1

Research Design Source: Prepared by Author 


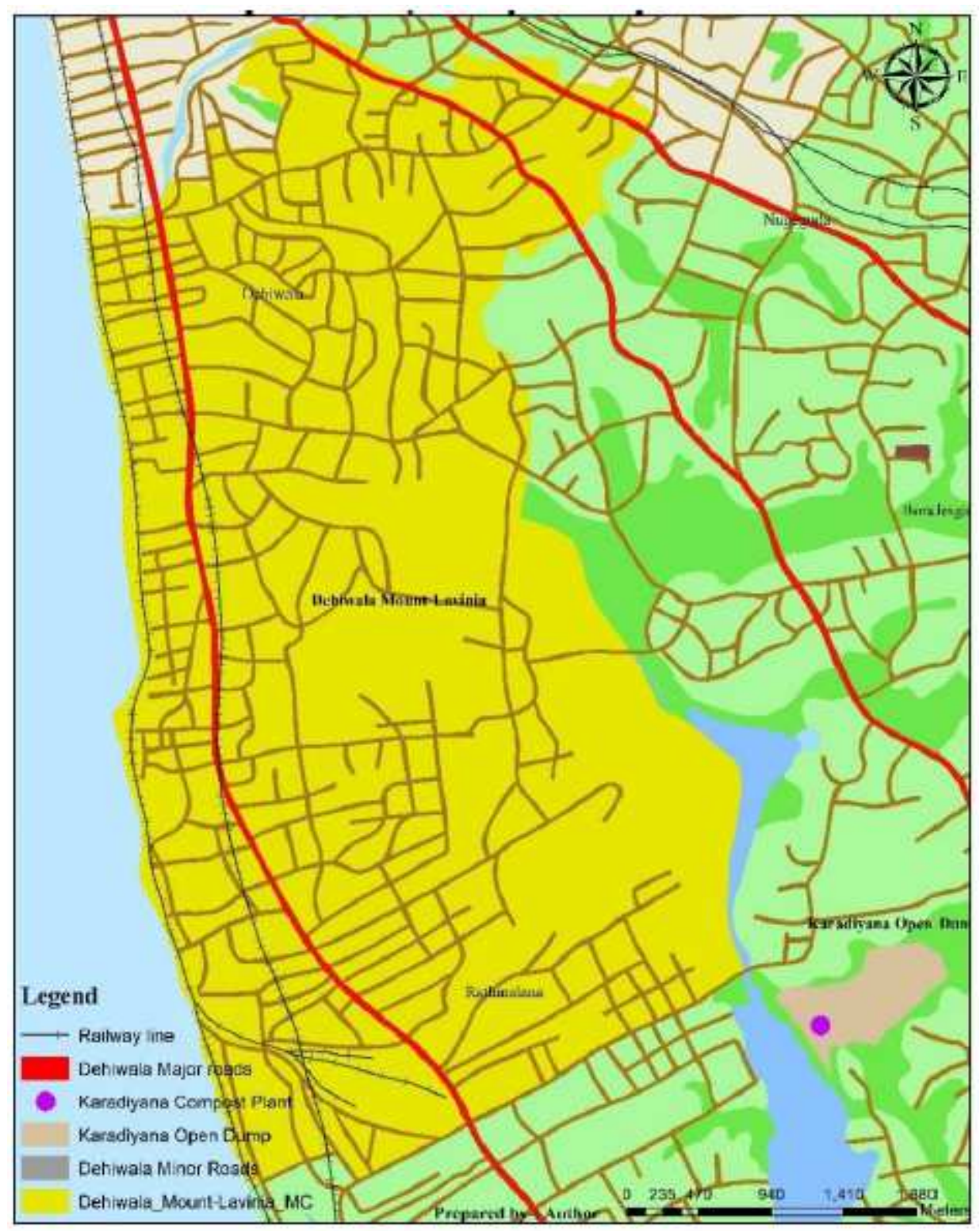

Figure 2

Location map of selected case study area Source-: Prepared by Author Note: The designations employed and the presentation of the material on this map do not imply the expression of any opinion whatsoever on the part of Research Square concerning the legal status of any country, territory, city or area or of its authorities, or concerning the delimitation of its frontiers or boundaries. This map has been provided by the authors. 


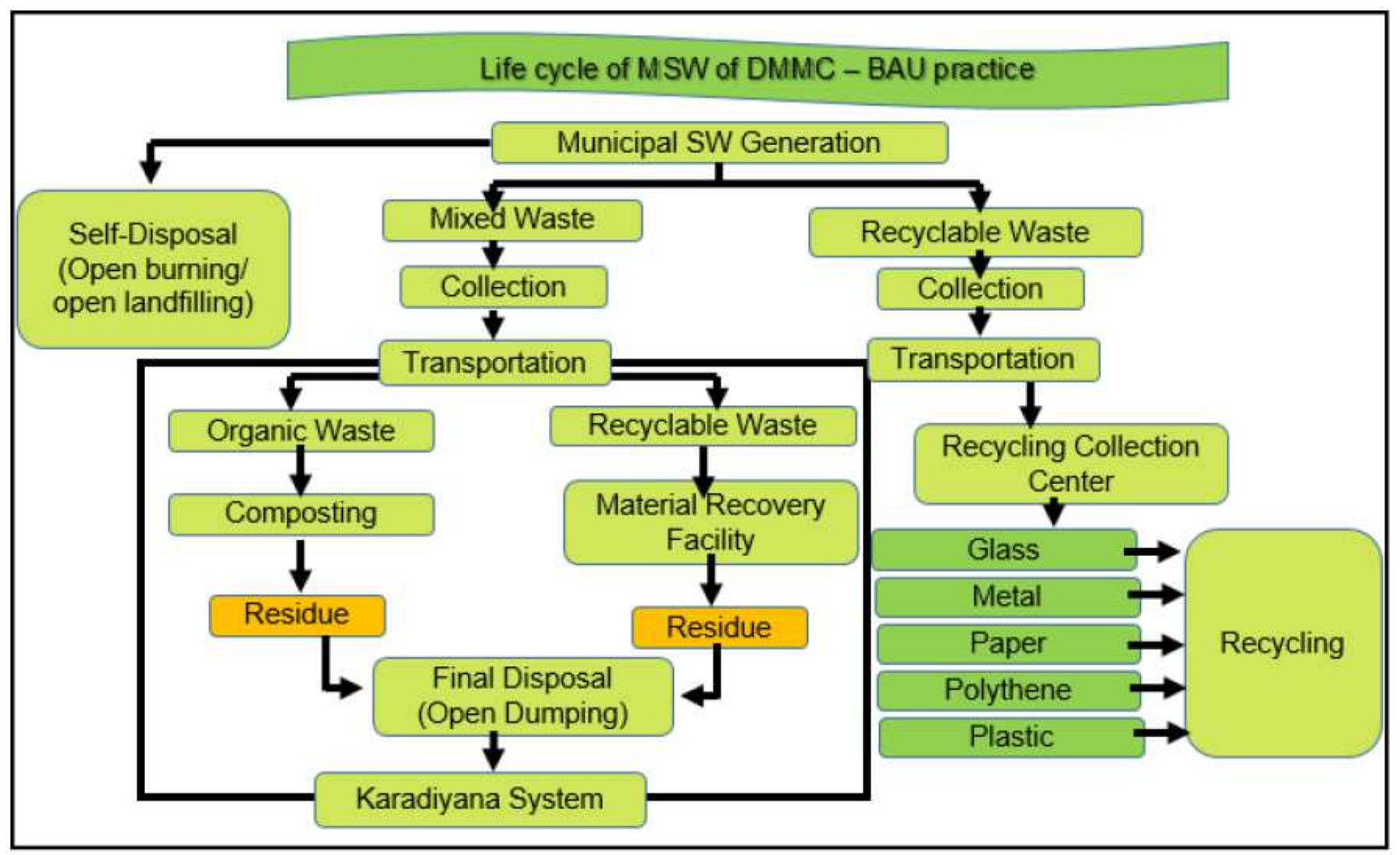

Figure 3

Life cycle of MSW of DMMC - BAU practice Source-: Discussions by Dehiwala-Mount Lavinia Municipal Council 


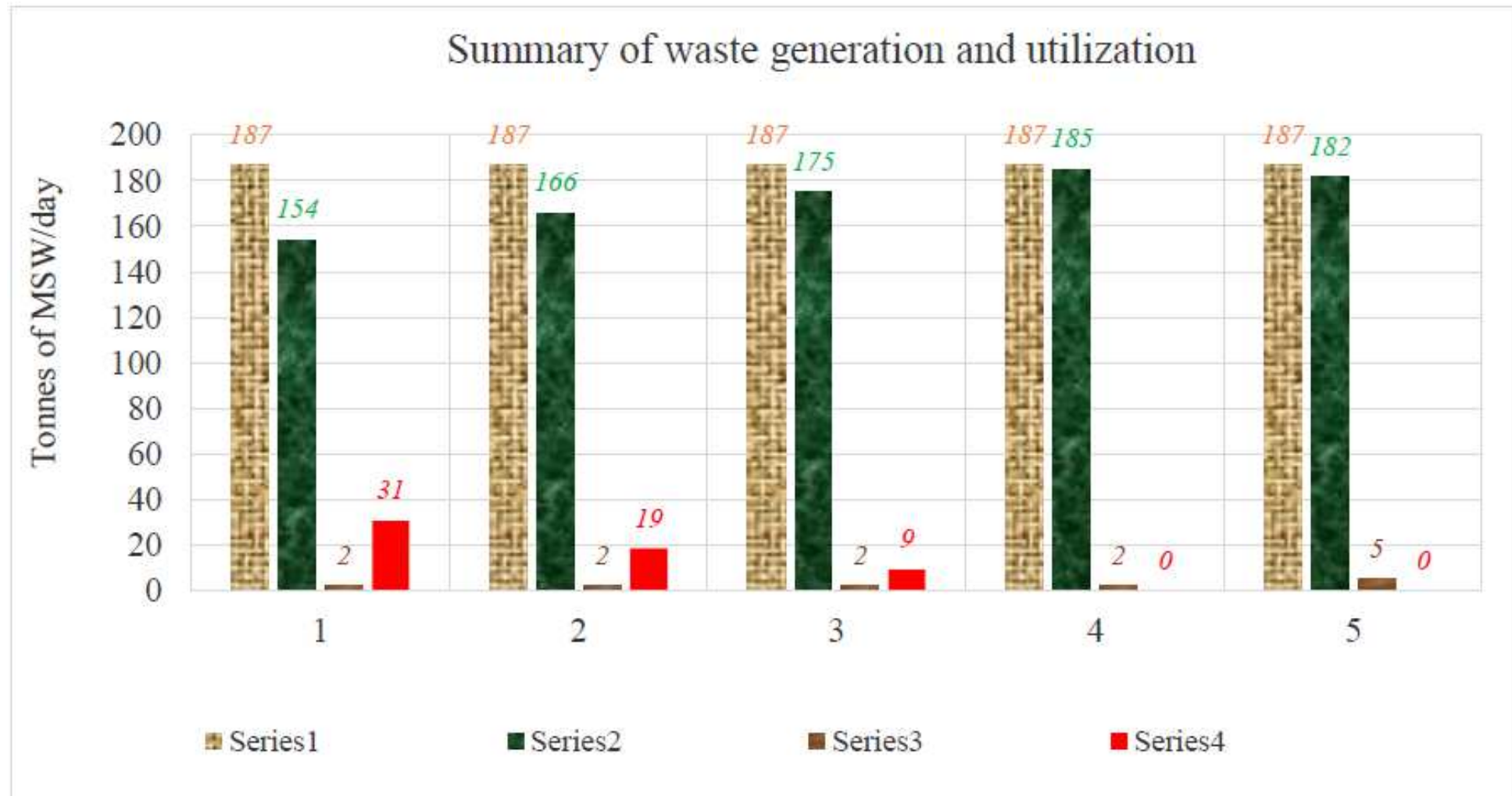

Figure 4

Summary of waste generation, collection and utilization Source-: Prepared by Author

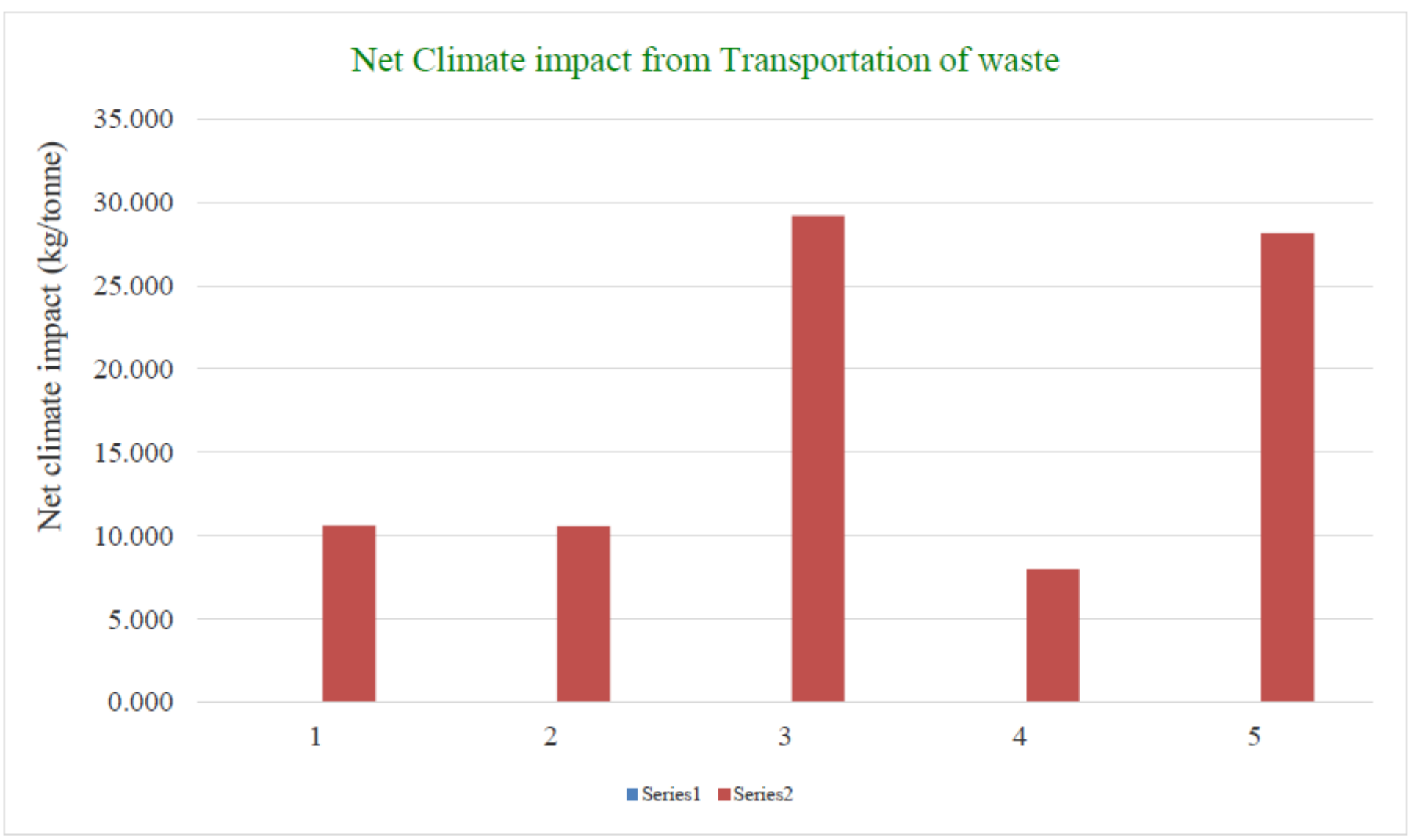

Figure 5 
Net climate impact from transportation Source-: Prepared by Author

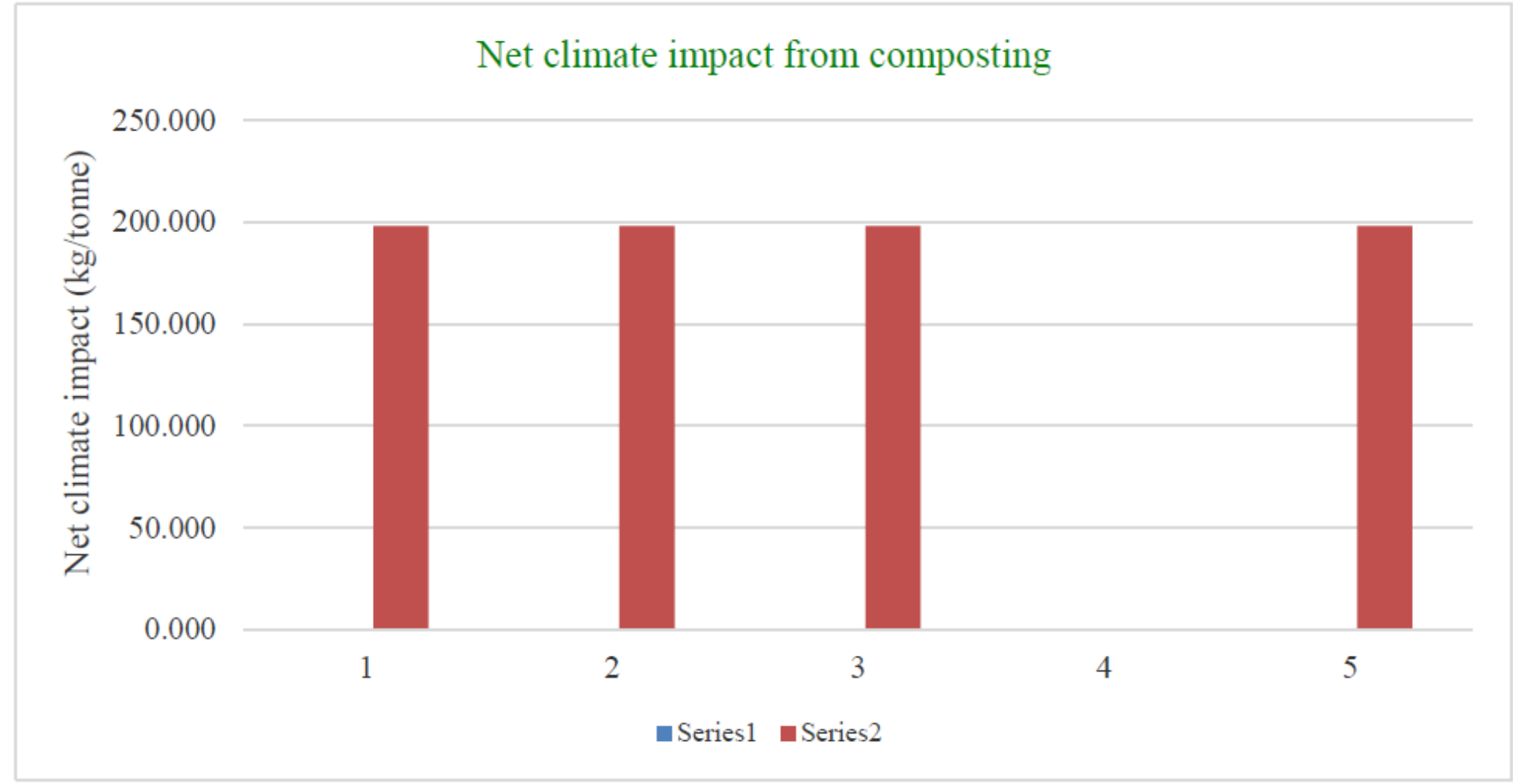

Figure 6

Net climate impact from composting Source-: Prepared by Author

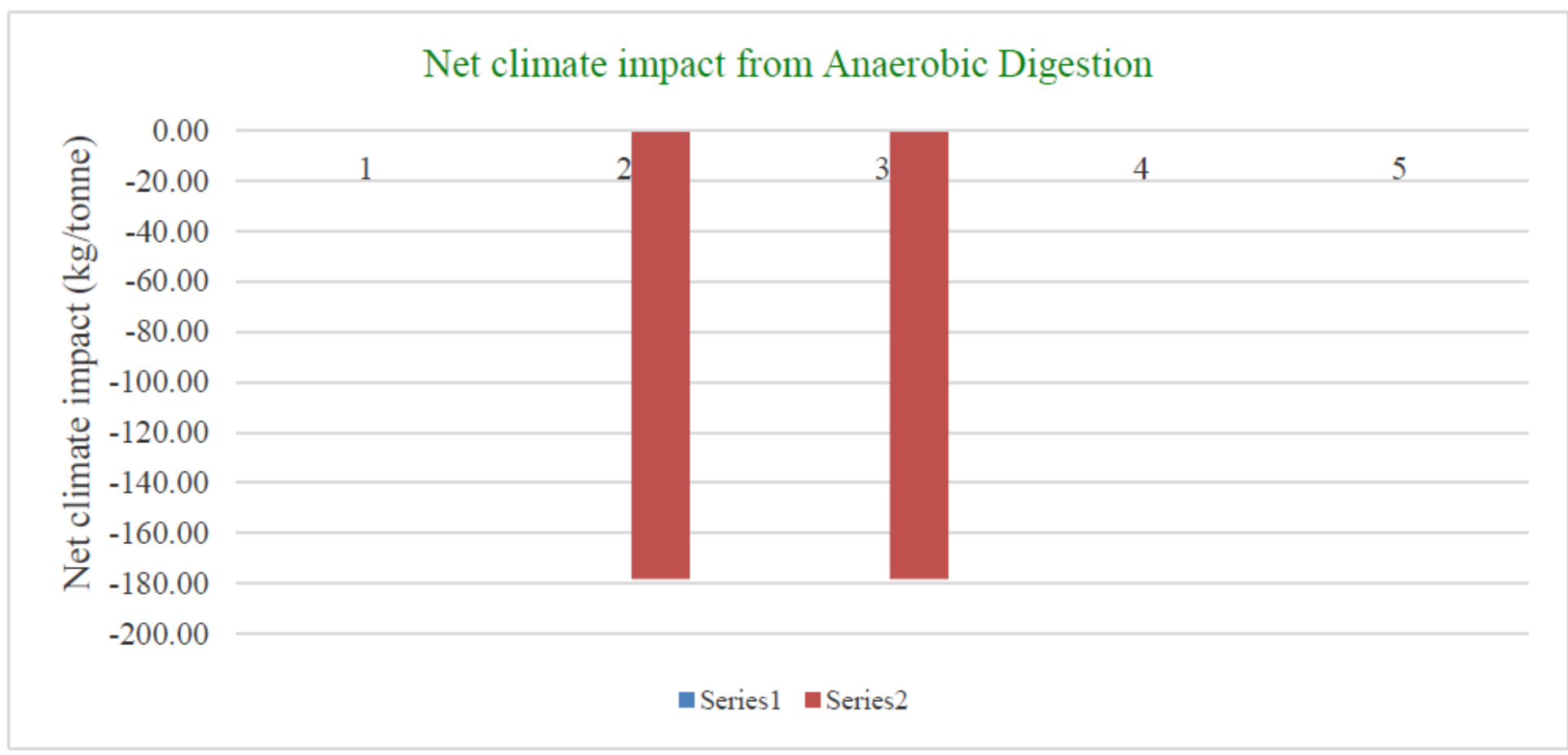

\section{Figure 7}

Net climate impact from AD Source-: Prepared by Author 


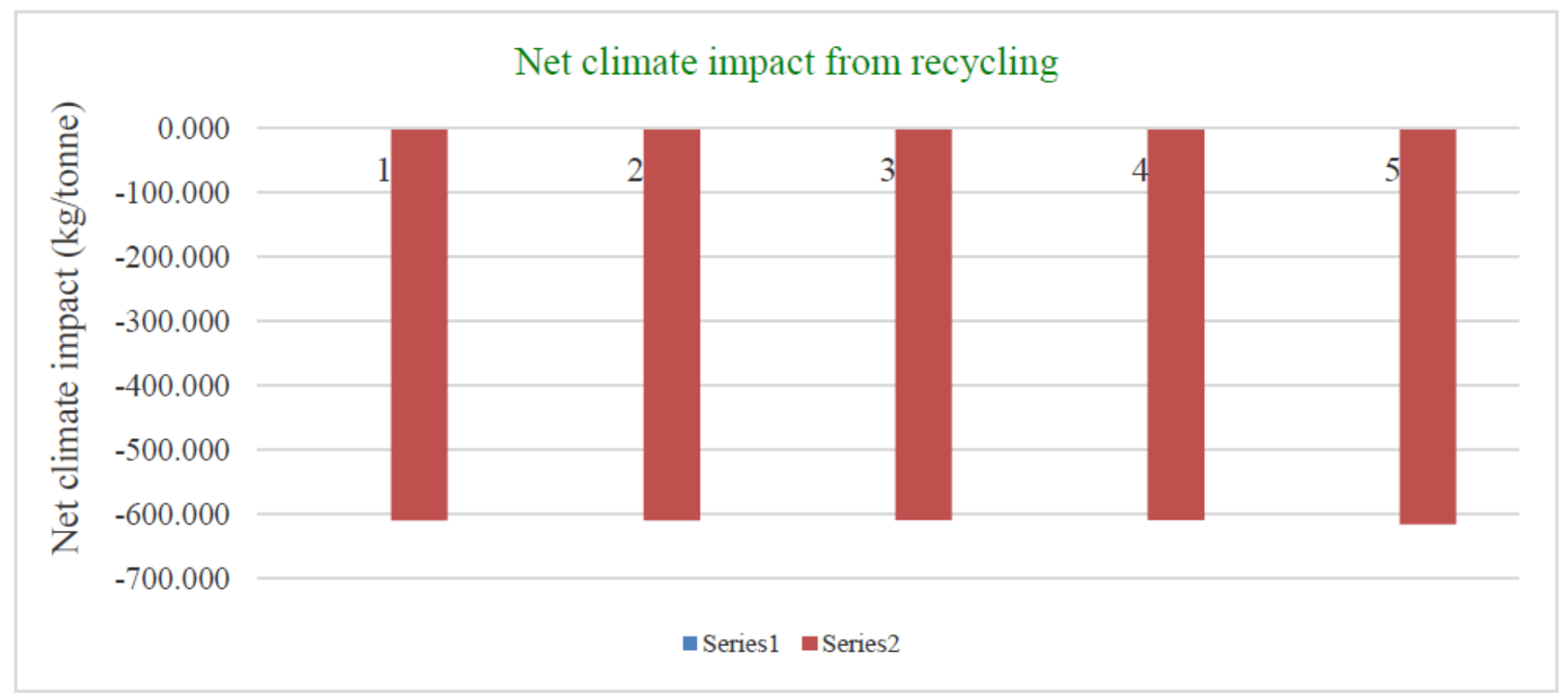

Figure 8

Net climate impact from Recycling Source-: Prepared by Author

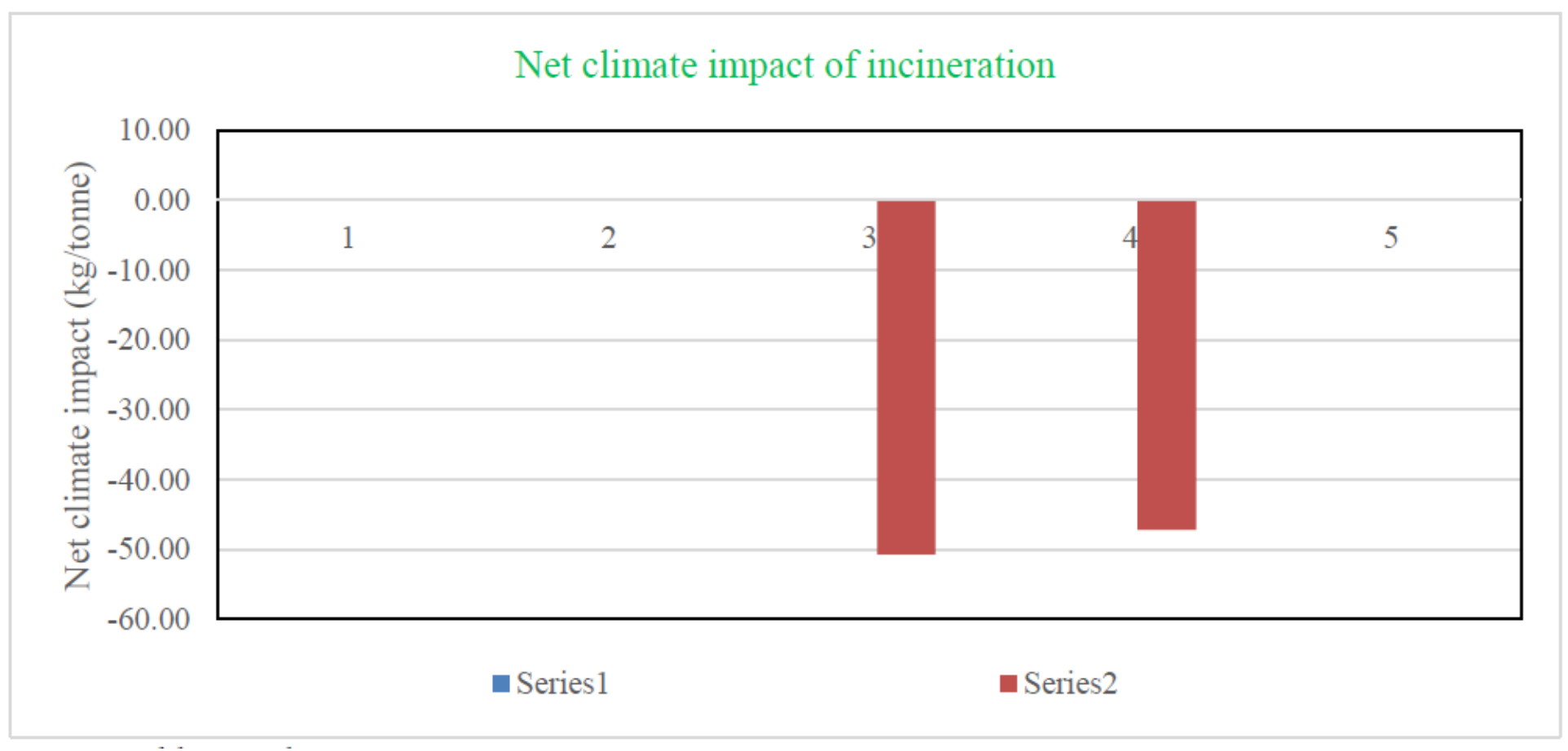

Figure 9

Net climate impact from Incineration Source-: Prepared by Author 


\section{Net climate impact from landfill/open dump}

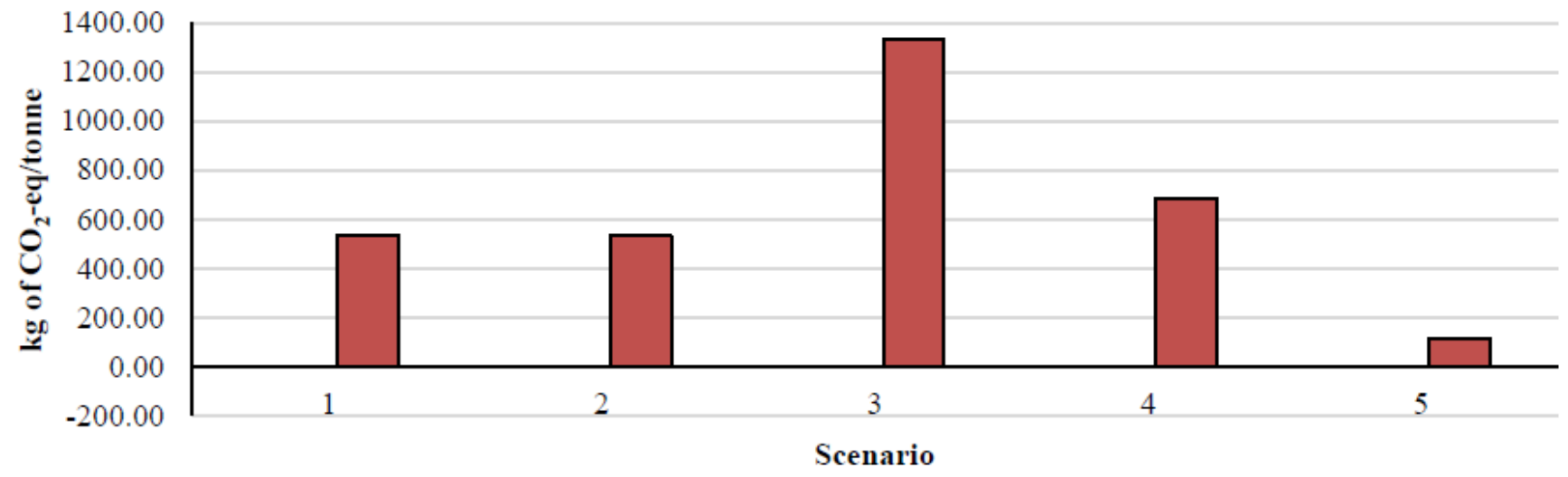

- Series1

$\square$ Series2

\section{Figure 10}

Net climate impact from landfill/open dumping Source-: Prepared by Author

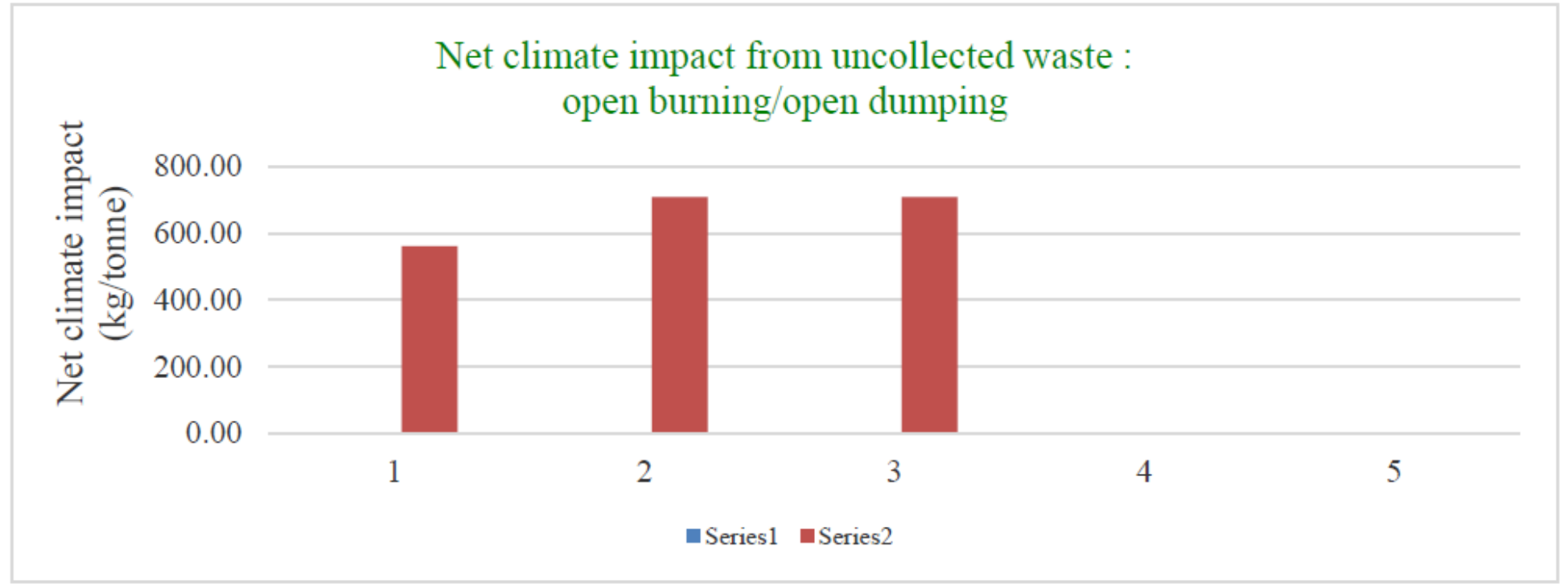

Figure 11

Net climate impact from uncollected waste Source-: Prepared by Author 


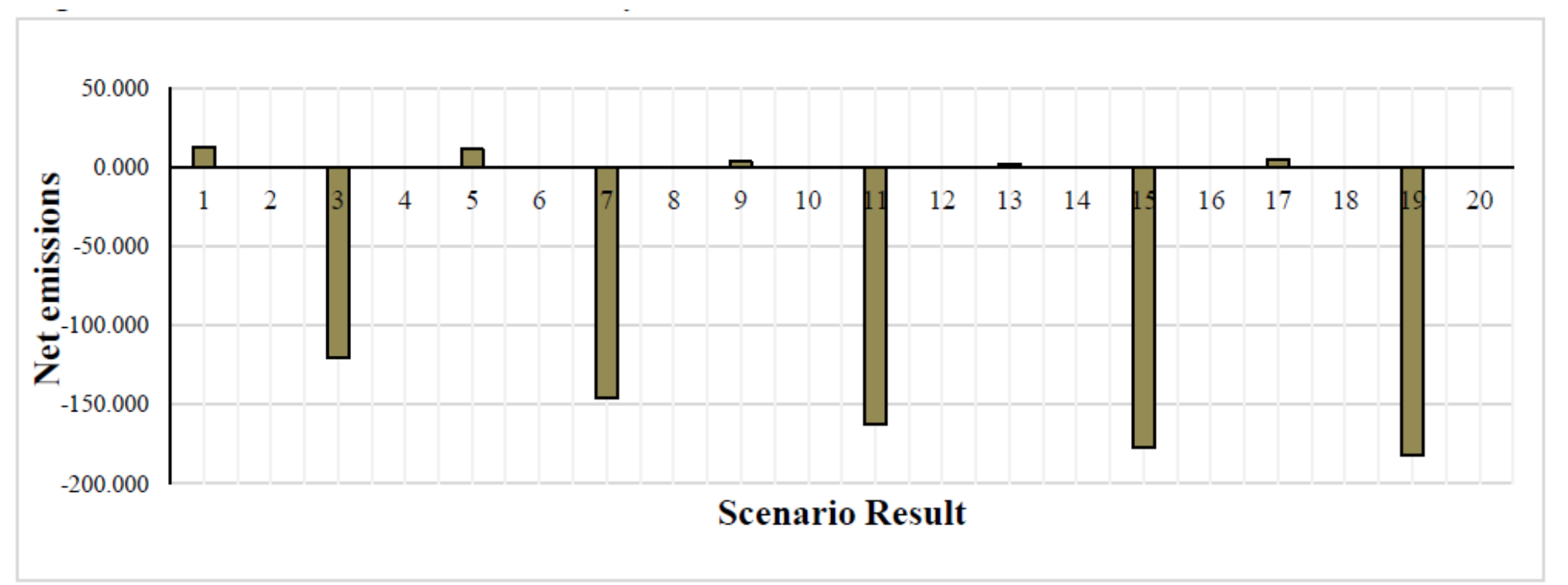

Figure 12

GHGs/ SLCPs emissions by Scenario Source-: Prepared by Author based on EQT Framework

DClimate impact from GHGs emissions per tonne of generated waste: $\mathrm{kg}$ of CO2-eq/tonne

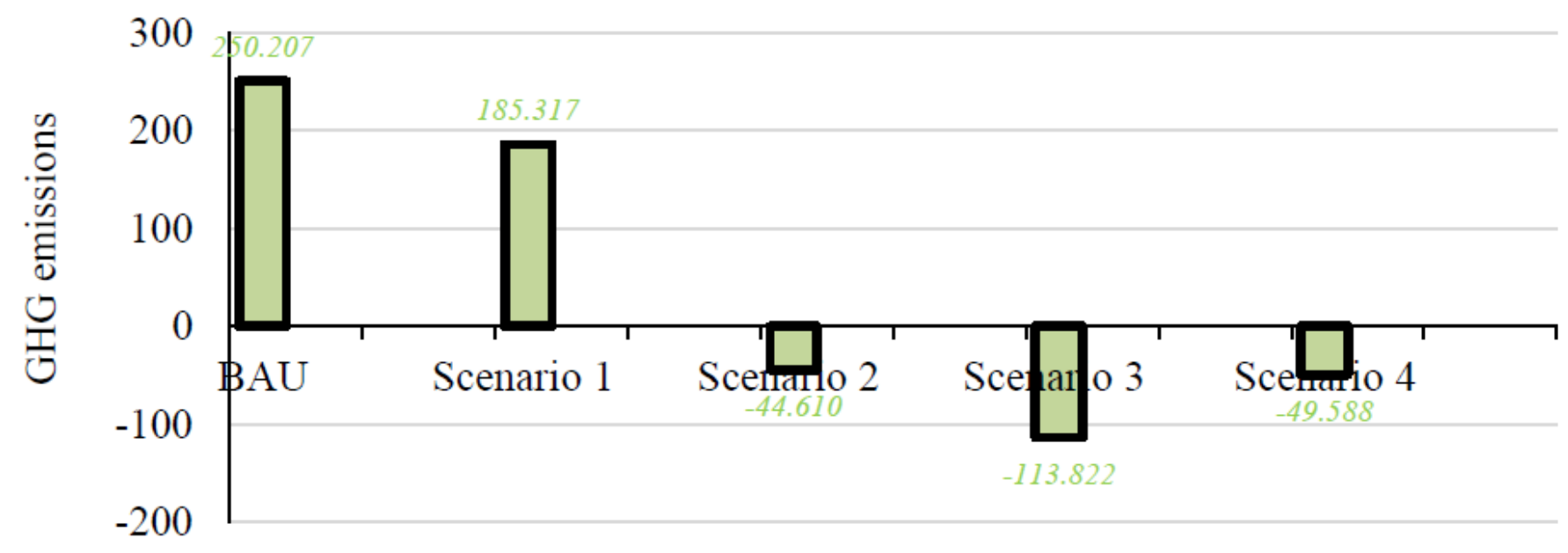

Figure 13

Climate impact from GHGs emissions per tonne of generated waste Source-: Prepared by Author based on EQT Framework

\section{Supplementary Files}

This is a list of supplementary files associated with this preprint. Click to download.

- ListofAnnexuresLCAbasedWMStrategy.pdf 